\title{
Y-12 GROUNDWATER PROTECTION PROGRAM MONITORING OPTIMIZATION PLAN FOR GROUNDWATER MONITORING WELLS AT THE \\ U.S. DEPARTMENT OF ENERGY Y-12 NATIONAL SECURITY COMPLEX, OAK RIDGE, TENNESSEE \\ Revision 1
}

Y-12

NATIONAL SECURITY COMPLEX
December 2009

Prepared by

ELVADO ENVIRONMENTAL LLC

Under Subcontract No. 4300068789

for the

Environmental Compliance Department Environment, Safety, and Health Division Y-12 National Security Complex Oak Ridge, Tennessee 37831

Managed by

Babcock \& Wilcox Technical Services Y-12, LLC for the U.S. DEPARTMENT OF ENERGY under contract No. DE-AC05-00OR22800 


\section{DISCLAIMER}

This report was prepared as an account of work sponsored by an agency of the United States Government. Neither the United States Government nor any agency thereof, nor any of their employees, makes any warranty, express or implied, or assumes any legal liability or responsibility for the accuracy, completeness, or usefulness of any information, apparatus, product, or process disclosed, or represents that its use would not infringe privately owned rights. Reference herein to any specific commercial product, process, or service by trade name, trademark, manufacturer, or otherwise, does not necessarily constitute or imply its endorsement, recommendation, or favoring by the United States Government or any agency thereof. The views and opinions of authors expressed herein do not necessarily state or reflect those of the United States Government or any agency thereof. 


\section{Y-12 GROUNDWATER PROTECTION PROGRAM MONITORING OPTIMIZATION PLAN FOR GROUNDWATER MONITORING WELLS AT THE \\ U.S. DEPARTMENT OF ENERGY Y-12 NATIONAL SECURITY COMPLEX, OAK RIDGE, TENNESSEE Revision 1}

December 2009

\section{Prepared by}

ELVADO ENVIRONMENTAL LLC

Under Subcontract No. 4300068789

for the

Environmental Compliance Department Environment, Safety, and Health Division Y-12 National Security Complex

Oak Ridge, Tennessee 37831

\section{Managed by}

Babcock \& Wilcox Technical Services Y-12, LLC for the U.S. DEPARTMENT OF ENERGY under contract No. DE-AC05-00OR22800 


\section{CONTENTS}

$\underline{\text { Section }} \quad \underline{\text { Page }}$

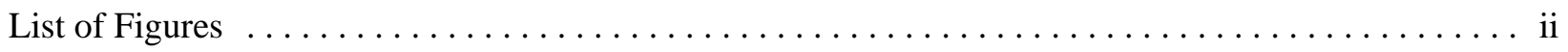

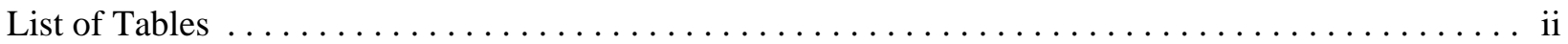

List of Acronyms and Abbreviations $\ldots \ldots \ldots \ldots \ldots \ldots \ldots \ldots \ldots \ldots \ldots \ldots \ldots \ldots \ldots \ldots \ldots \ldots \ldots \ldots \ldots \ldots$

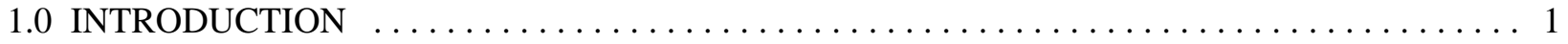

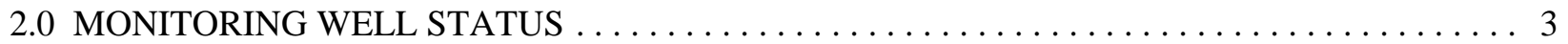

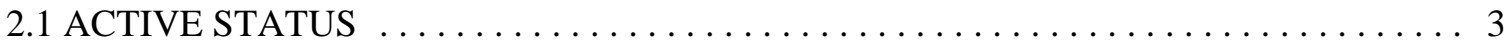

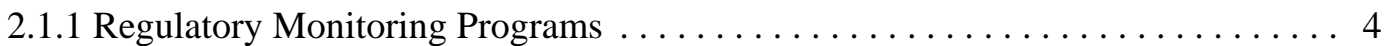

2.1.2 DOE Order 450.1A Surveillance Monitoring . . . . . . . . . . . . . 4

2.1.3 Hydrologic Monitoring . . . . . . . . . . . . . . . . . . . . . . . 5

2.1.4 Qualitative Review ............................ 6

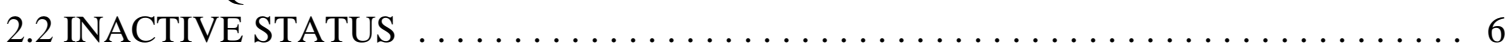

3.0 MONITORING WELL UTILIZATION $\ldots \ldots \ldots \ldots \ldots \ldots \ldots \ldots \ldots \ldots \ldots \ldots \ldots \ldots$

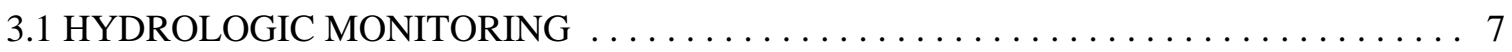

3.2 GROUNDWATER QUALITY SAMPLING $\ldots \ldots \ldots \ldots \ldots \ldots \ldots \ldots \ldots \ldots \ldots \ldots \ldots$

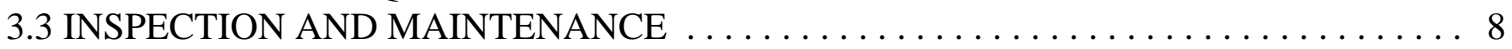

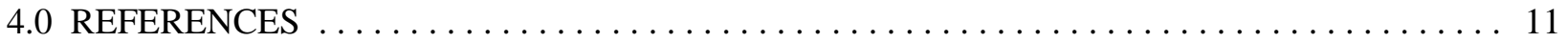

APPENDIX A: FIGURES

APPENDIX B: TABLES

APPENDIX C: ADDENDA 


\section{List of Figures}

Figure

Page

A.1 Hydrogeologic regimes at the Y-12 National Security Complex $\ldots \ldots \ldots \ldots \ldots \ldots \ldots$ A-1

A.2 Process used to designate the status of groundwater monitoring wells at the

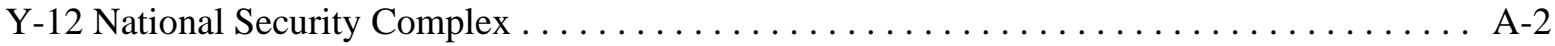

A.3 Locations of groundwater monitoring wells in the Bear Creek Hydrogeologic Regime that are granted active status under the Y-12 Groundwater Protection Program $\ldots \ldots \ldots \ldots$ A-3

A.4 Locations of groundwater monitoring wells in the Upper East Fork Poplar Creek Hydrogeologic Regime that are granted active status under the Y-12 Groundwater

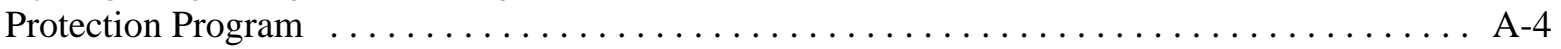

A.5 Locations of groundwater monitoring wells in the Chestnut Ridge Hydrogeologic Regime that are granted active status under the Y-12 Groundwater Protection Program

\section{List of Tables}

$\underline{\text { Table }}$

B.1 Groundwater monitoring wells that are granted active status under the

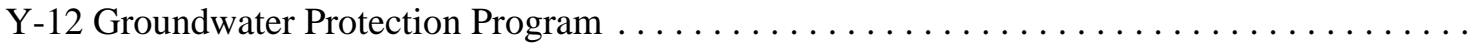

B.2 Groundwater monitoring wells that are granted inactive status under the Y-12 Groundwater Protection Program 


\section{List of Acronyms and Abbreviations}

B\&W Y-12
Bear Creek Regime
BCV
BWXT
Chestnut Ridge Regime
CERCLA
DOE
East Fork Regime
GWPP
MAROS
ORR
PCP
RCRA
SAP
SPM
SWDF
Y-12

Babcock \& Wilcox Technical Services Y-12, LLC

Bear Creek Hydrogeologic Regime

Bear Creek Valley

BWXT Y-12, L.L.C.

Chestnut Ridge Hydrogeologic Regime

Comprehensive Environmental Response, Compensation, and Liability Act U.S. Department of Energy

Upper East Fork Poplar Creek Hydrogeologic Regime

Groundwater Protection Program

Monitoring and Remediation Optimization System

Oak Ridge Reservation

post-closure permit

Resource Conservation and Recovery Act

sampling and analysis plan

selective parameter monitoring

Solid Waste Disposal Facility

Y-12 National Security Complex 


\subsection{INTRODUCTION}

This document is the monitoring optimization plan for groundwater monitoring wells associated with the U.S. Department of Energy (DOE) Y-12 National Security Complex (Y-12) in Oak Ridge, Tennessee (Figure A.1). The plan describes the technical approach that will be implemented under the Y-12 Groundwater Protection Program (GWPP) to focus available resources on the monitoring wells at Y-12 that provide the most useful hydrologic and groundwater quality monitoring data. The technical approach is based on the GWPP status designation for each well (Section 2.0). Under this approach, wells granted "active" status are used by the GWPP for hydrologic monitoring and/or groundwater quality sampling (Section 3.0), whereas wells granted "inactive" status are not used for either purpose. The status designation also defines the frequency at which the GWPP will inspect applicable wells, the scope of these well inspections, and extent of any maintenance actions initiated by the GWPP (Section 3.0). Details regarding the ancillary activities associated with implementation of this plan (e.g., well inspection) are deferred to the referenced GWPP plans and procedures (Section 4.0).

This plan applies to groundwater wells associated with Y-12 and related waste management areas and facilities located within three hydrogeologic regimes (Figure A.1): the Bear Creek Hydrogeologic Regime (Bear Creek Regime), the Upper East Fork Poplar Creek Hydrogeologic Regime (East Fork Regime), and the Chestnut Ridge Hydrogeologic Regime (Chestnut Ridge Regime). The Bear Creek Regime encompasses a section of Bear Creek Valley (BCV) immediately west of Y-12. The East Fork Regime encompasses most of the $\mathrm{Y}-12$ process, operations, and support facilities in BCV and, for the purposes of this plan, includes a section of Union Valley east of the DOE Oak Ridge Reservation (ORR) boundary along Scarboro Road. The Chestnut Ridge Regime encompasses a section of Chestnut Ridge directly south of Y-12 that is bound on the west by a surface drainage feature (Dunaway Branch) and on the east by Scarboro Road. For this plan, the Chestnut Ridge Regime includes an area known as the South Campus Facility that is located west of Scarboro Road and south of Bethel Valley Road. The GWPP maintains an extensive database of construction details and related information for the monitoring wells in each hydrogeologic regime (including wells that have been destroyed or intentionally plugged and abandoned); the most recent hardcopy version of the database was issued in February 2003 (BWXT Y-12, L.L.C. [BWXT] 2003).

This plan does not apply to temporary piezometers or other specialized groundwater monitoring/sampling devices that have been or may be installed for research purposes, hydrologic tests, pilot studies, or short-term investigations. Additionally, this document does not apply to 141 groundwater monitoring wells located in western BCV that were formerly maintained by the GWPP before organizational stewardship responsibility was relinquished in February 2006.

As specified in the Y-12 GWPP Management Plan (Babcock \& Wilcox Technical Services Y-12, LLC [B\&W Y-12] 2009a), this plan will be reviewed and updated every three years. Between scheduled updates, addenda issued by the GWPP Manager (or authorized designee) will document any substantial changes or modifications to the plan, including changes in the GWPP status designation for each monitoring well identified in the plan. The addenda, numbered in consecutive ascending order, will be forwarded to all personnel included on the distribution list for this plan. The addenda are inserted in Appendix $C$ pending the next scheduled update of the plan, which will incorporate the information included in the addenda. This revision of the monitoring optimization plan incorporates the four addenda issued to the previous version. 


\subsection{MONITORING WELL STATUS}

For the purposes of this plan, the existing groundwater monitoring wells at $\mathrm{Y}-12$ are assigned active status (Table B.1) or inactive status (Table B.2) in accordance with the decision process illustrated on Figure A.2. Although the wells granted either status may be functionally suitable for hydrologic monitoring and groundwater sampling, only wells granted active status will be used for either purpose by the GWPP.

The wells in each hydrogeologic regime that are granted active or inactive status under the GWPP reflect decisions made in response to the findings of an independent assessment of the GWPP that was completed in December 2005 (BWXT 2005) and a subsequent supplemental assessment completed in January 2009 (B\&W Y-12 2009b). Both assessments, hereafter referenced as the baseline GWPP assessment and the supplemental GWPP assessment, respectively, included quantitative evaluations performed using Monitoring and Remediation Optimization System (MAROS) proprietary computer software. Only data that meet GWPP data quality objectives (DQOs) were used as MAROS input, with sampling results from January 1995 December 2004 evaluated under the baseline GWPP assessment and sampling results from January 1986 December 2007 evaluated under the supplemental GWPP assessment. Quantitative evaluations performed by the MAROS software included temporal trend analyses (linear regression) and non-parametric trend analyses (Mann-Kendall) for each applicable contaminant of concern (COC) in the groundwater at each well. Also, for each COC, the MAROS software performed spatial analyses using a weighted "area-of-influence" approach (implemented using Delaunay triangulation) to determine the relative value (significance) of data generated by each well. monitoring and thereby identify the optimal monitoring locations. For each applicable well, the results of these MAROS-based "well sufficiency" and "well redundancy" analyses from the baseline and supplemental assessments of the GWPP were factored into the designation of active or inactive well status.

The designated status of each well will not change unless warranted by future circumstances and approved by the GWPP Manager. For example, a well that currently is granted inactive status may be used to replace a nearby well granted active status that has been irreparably damaged or destroyed. Whenever a change in the status of a well is warranted, the GWPP Manager (or authorized designee) will issue an addendum to this plan that identifies the well and the reason(s) for the change in status.

\subsection{ACTIVE STATUS}

Active status under the GWPP, based on one or more of the considerations described in the following subsections, is granted to a total of 352 wells at Y-12 (Table B.1), including 133 wells designated for use in one or more regulatory monitoring programs; 146 wells that specifically address site-wide monitoring requirements of DOE Order 450.1A Environmental Protection Program; and 227 wells used to monitor groundwater surface elevations. Note that approximately $40 \%$ of the wells granted active status meet more than one of the criteria mentioned above (Table B.1). The wells granted active status include 134 wells located in the Bear Creek Regime (Figure A.3), 132 wells located in the East Fork Regime (Figure A.4), and 86 wells located in the Chestnut Ridge Regime (Figure A.5).

Active status under the GWPP also will be granted to any newly installed well that meets the design and construction standards described in the Monitoring Well Installation Plan for the Department of Energy Y-12 Plant (Lockheed Martin Energy Systems, Inc. 1997) and serves an ongoing regulatory monitoring program, or provides data suited to the technical purposes or programmatic objectives of the GWPP. New wells that 
do not meet these criteria will be granted inactive status. In either case, the GWPP Manager (or authorized designee) will issue an addendum to this plan to incorporate data for any new wells installed at Y-12.

\subsubsection{Regulatory Monitoring Programs}

Active status is granted to each groundwater monitoring well that is identified in the current respective Resource Conservation and Recovery Act (RCRA) post-closure permit (PCP) for the Bear Creek Regime, East Fork Regime, and Chestnut Ridge Regime. Each respective PCP defines the requirements for RCRA post-closure groundwater monitoring at the specified sites in the corresponding hydrogeologic regime. Collectively, the PCPs designate a total of 61 wells for RCRA post-closure detection monitoring and RCRA post-closure corrective action monitoring (Table B.1), including 25 wells located in the Bear Creek Regime, nine wells located in the East Fork Regime, and 27 wells located in the Chestnut Ridge Regime.

Active status is granted to each groundwater monitoring well that is specified in a Comprehensive Environmental Response, Liability, and Compensation Act (CERCLA) interim/final record of decision or the related decision document(s) for applicable facilities at Y-12. A total of 75 wells at Y-12 are monitored specifically for CERCLA-related groundwater monitoring purposes (Table B.1), including 25 wells located in the Bear Creek Regime, 37 wells located in the East Fork Regime, and 13 wells located in the Chestnut Ridge Regime (Bechtel Jacobs Company LLC 2009). Twelve of these wells (four wells in each regime) also are listed in the respective PCPs (Table B.1). Note that the CERCLA wells located in the Bear Creek Regime include those used for groundwater quality monitoring at the Environmental Management Waste Management Facility.

Active status is granted to the 13 wells designated for SWDF detection monitoring at three active and inactive (closed) nonhazardous solid waste landfills located in the Chestnut Ridge Regime (Table B.1): Industrial Landfill II, Industrial Landfill V, and Construction/Demolition Landfill VII. Active status also is granted to five wells designated for SWDF Assessment Monitoring Phase II at Industrial Landfill IV. Six of the wells designated for SWDF monitoring also are used for RCRA monitoring per the PCP for the Chestnut Ridge Regime and three of the SWDF monitoring wells also serve CERCLA monitoring requirements.

Ongoing RCRA-, CERCLA-, and SWDF-related groundwater sampling and analysis activities in each hydrogeologic regime at Y-12 are not implemented under the GWPP. Nevertheless, all the monitoring programs employ technically equivalent groundwater sampling methods and laboratory analytical procedures. Consequently, the field and laboratory data obtained for the regulatory monitoring programs meet the data quality objectives of the GWPP, as defined in the most recent version of the Y-12 GWPP Data Management Plan (BWXT 2006a).

\subsubsection{DOE Order 450.1A Monitoring}

Active status is granted to each well at Y-12 that serves DOE Order 450.1A requirements for site-wide monitoring. DOE Order 450.1A and associated DOE guidance documents collectively outline the following requirements for and objectives of site-wide monitoring, hereafter referenced as DOE Order Monitoring, of groundwater that has been or could be impacted by facility operations at Y-12:

- determine baseline conditions of groundwater quality and quantity; 
- demonstrate compliance with and implementation of all applicable state and federal regulations and DOE orders;

- ensure early detection of groundwater pollution or contamination from an operating facility or practice and provide an early warning to trigger appropriate response actions to unplanned releases of contaminants to the subsurface;

- identify existing and potential groundwater contamination sources and to maintain surveillance of these sources;

- evaluate groundwater quality in areas where contaminants have the potential to migrate offsite;

- meet long-term objectives for monitoring in areas where wastes and other subsurface contaminants will remain after all active site operations have ceased; and

- support decisions concerning land-use practices and the management of groundwater resources.

To achieve the purpose and objectives of DOE Order Monitoring, the GWPP performs hydrologic and groundwater quality monitoring in conjunction with concurrent, regulatory-driven (RCRA, CERCLA, and SWDF) monitoring performed by other organizations. In accordance with DOE technical guidance (DOE 2006), DOE Order Monitoring includes facility (source)/contaminant plume monitoring (referenced as Surveillance Monitoring) and exit pathway/perimeter monitoring (referenced as Exit Pathway Monitoring). All sampling and analysis activities associated with Surveillance Monitoring and Exit Pathway Monitoring in each hydrogeologic regime are performed in accordance with standardized GWPP monitoring protocols described and/or referenced in the annual Sampling and Analysis Plan (SAP) issued by the GWPP. Surveillance Monitoring and Exit Pathway Monitoring data (field measurements and analytical results) obtained each calendar year are included in the annual Groundwater Monitoring Report (GWMR) issued by the GWPP.

Groundwater sampling and analysis activities for Surveillance Monitoring under the GWPP are directed at areas of known, suspected, or potential sources of groundwater contamination at Y-12 that are not otherwise addressed under the ongoing RCRA, CERCLA, and SWDF monitoring programs. Surveillance Monitoring also encompasses groundwater sampling and analysis activities associated with any special hydrogeologic studies implemented by the GWPP. To provide early detection of impacts to groundwater, the wells used for Surveillance Monitoring are located in close proximity to active Y-12 facilities and operations, and include 55 of the active status wells in the Bear Creek Regime, 72 of the active status wells in the East Fork Regime, and 11 of the active status wells in the Chestnut Ridge Regime (Table B.1). The number of wells sampled for Surveillance Monitoring changes from year to year, depending on monitoring optimization and funding levels, and varies between hydrogeologic regimes at Y-12, depending on the extent of monitoring coverage provided by the RCRA, CERCLA, and SWDF monitoring programs.

Exit Pathway Monitoring under the GWPP involves collection of groundwater samples from generally fixed networks of perimeter and exit pathway monitoring stations (wells and surface water sampling points) in the Bear Creek and East Fork hydrogeologic regimes, and from selected springs and sampling points in surface drainage features that traverse the Chestnut Ridge Regime (Table B.1). The designated perimeter monitoring wells in the Bear Creek Regime are located about 6,500 ft southwest of the BCBG along a strike-normal transect across the Maynardville Limestone (Figure A.3), which is the primary exit pathway for Y-12 
groundwater contaminants to migrate to westward beyond the ORR property boundary. Several perimeter monitoring wells at the eastern end of Y-12 in the East Fork Regime also are located along a strike-normal transect across the Maynardville Limestone, with additional perimeter wells located northeast of Y-12 where Upper East Fork Poplar Creek passes through a gap in Pine Ridge (Figure A.4). Instead of perimeter monitoring wells in the Chestnut Ridge Regime, a series of springs and surface water monitoring locations along local surface drainage features on the southern flank of Chestnut Ridge are sampled for the purposes of Exit Pathway Monitoring (Figure A.5).

\subsubsection{Hydrologic Monitoring}

Active status is granted to each groundwater monitoring well that is part of the respective regime-wide network of wells used for monitoring groundwater surface elevations in the Bear Creek Regime, East Fork Regime, and Chestnut Ridge Regime. Section 3.1 provides details regarding the hydrologic monitoring wells in each regime. Using fixed networks of hydrologic monitoring wells in each regime ensures that the GWPP obtains adequate, equivalent, consistent, and representative groundwater elevation data.

\subsubsection{Qualitative Review}

Regardless of the other applicable criteria, active status may be granted to any well at Y-12 that, based on the objective professional judgement of the GWPP Manager, is considered suitable for the technical purposes and/or programmatic objectives of the GWPP.

\subsection{INACTIVE STATUS}

Inactive status under the GWPP currently is granted to 195 groundwater wells at Y-12 (Table B.2). The wells that are granted inactive status fall under one of the following generalized groups:

- Wells for which the design and construction details are unknown or do not meet the technical standards of the GWPP, or wells that do not meet other GWPP requirements (e.g., all-weather access).

- Wells for which groundwater quality and hydrologic monitoring data are not available or needed.

- Wells that are not located hydraulically downgradient of any facility associated with Y-12 and/or any confirmed or potential source(s) of groundwater contamination.

- Wells that are known to yield uncontaminated groundwater hydraulically downgradient of a facility associated with Y-12, and/or any confirmed or potential source(s) of groundwater contamination, but do not provide unique monitoring coverage.

- Wells for which the baseline or supplemental assessment recommended discontinued sampling under the GWPP (Figure A.2), excluding wells determined by the GWPP Manager to serve the technical or programmatic purposes of the GWPP. 
As noted in Sect. 2.2, the MAROS-based quantitative evaluations performed as part of the baseline and supplemental assessments of the GWPP included statistical analysis of "well redundancy" to identify wells which provide data that are less "significant" than data for one or more neighboring wells and, therefore, do not warrant continued groundwater sampling (unless specifically required under a regulatory-driven monitoring program). From the baseline GWPP assessment, results of the MAROS "well redundancy" evaluation supported recommendations to discontinue groundwater sampling for 122 wells (BWXT 2005), and findings of the MAROS "well redundancy" evaluation from the supplemental GWPP assessment support recommendations to discontinue sampling of groundwater from 29 wells (B\&W Y-12 2009b). On the basis of these quantitative evaluations, and the professional judgement of the GWPP Manager, recommendations for discontinued sampling were accepted for all but 11 of these wells. 


\subsection{MONITORING WELL UTILIZATION}

As described in the following subsections, each groundwater monitoring well at Y-12 that is granted active status under the GWPP is generally suitable for hydrologic monitoring and/or groundwater quality sampling. To ensure their continued use for either purpose, the wells will be appropriately inspected and maintained, with more frequent inspection and proactive maintenance focused on wells granted active status.

\subsection{HYDROLOGIC MONITORING}

A total of 227 wells at Y-12 that are granted active status under the GWPP are designated for hydrologic monitoring (Table B.1), including 85 wells in the Bear Creek Regime, 64 wells in the East Fork Regime, and 77 wells in the Chestnut Ridge Regime. The respective network of hydrologic monitoring wells in each regime provides the geographic coverage needed to determine regime-wide groundwater surface elevations, evaluate localized groundwater flow patterns, and calculate representative horizontal and vertical hydraulic gradients.

The elevation of the groundwater surface throughout the Bear Creek Regime, East Fork Regime, and Chestnut Ridge Regime will be determined at least annually based on the depth-to-water measurements recorded for the hydrologic monitoring wells in each regime. The depth to water in each well will be measured in accordance with the most recent approved version of the applicable GWPP technical procedure or a functionally equivalent technical procedure. Annual depth-to-water measurements will be performed during alternating wet (winter and spring) and dry (summer and fall) seasonal flow conditions. To ensure the most contemporaneous regime-wide data, measurements of the depth to water in all of the hydrologic monitoring wells in each regime will be completed in the shortest time practical.

\subsection{GROUNDWATER QUALITY SAMPLING}

The GWPP defines the groundwater quality sampling requirements (sampling frequency, sampling method, field measurements, and laboratory analytes) for each well granted active status under the GWPP, excluding wells that serve RCRA, CERCLA, or SWDF monitoring programs, which have regulatory- and permit-driven (and technically equivalent) sampling protocols. The designated optimum sampling frequency only applies to sampling performed under the GWPP and does not replace or supercede any regulatory and/or permitdriven sampling frequency specified for applicable wells granted active status (e.g., wells designated for RCRA Monitoring).

The current groundwater sampling frequency appropriate for each applicable well granted active status is determined by results of MAROS-based quantitative evaluations performed under the supplemental assessment of the GWPP and subsequent professional judgement of the GWPP Manager (Table B.1). The MAROS output specified one of the following recommended sampling frequencies for each well: semiannual, annual, biennial, every five years, or eliminate (discontinue sampling). The supplemental GWPP assessment included wells designated for RCRA, CERCLA, SWDF monitoring so as to obtain the best sitewide representation of groundwater quality monitoring data, although the recommended sampling frequency for each of these wells is not actionable (the sampling frequency is specified by the governing regulatory program). 
Currently, 146 of the 352 wells at Y-12 that are granted active status are designated for groundwater quality sampling under the GWPP (Table B.1), including some wells that are alternate wells listed in RCRA PCPs and/or used for hydrologic monitoring. Although based on results of the MCES analysis, the current sampling frequency for each well reflects the results of a subsequent evaluation of each MAROS recommendation, which was performed and/or approved by the GWPP manager. This final evaluation also assigned the calendar year for sampling for the wells to be sampled every five years, and assigned "even" or "odd" as the sampling year for the wells with a biennial sampling frequency (Table B.1). A total of eight wells selected for groundwater quality sampling have not been assigned a sampling frequency by the GWPP and are classified as "to be determined" (Table B.1). The sampling frequency for these wells, which include 11 wells omitted from the MAROS evaluation and wells with MAROS recommendations of review (10 wells), remove (four wells), or sample (three wells), will be determined within the next few years.

The frequency at which groundwater samples are collected from wells specifically to meet requirements of DOE Order 450.1A surveillance monitoring also is identified in the annual SAP issued by the GWPP. The groundwater monitoring results obtained each year are evaluated in the annual Groundwater Monitoring Report (GWMR) issued by the GWPP. Based on the results of the annual evaluations, the GWMR may contain recommendations to alter the sampling frequency for monitoring wells. Any recommended changes will be evaluated by the GWPP manager and, if approved, will be reflected in the subsequent annual SAP issued by the GWPP and included as an addendum to this plan (Appendix C).

Only unfiltered groundwater quality samples are collected for the purposes of the GWPP; filtered samples are obtained only if specifically requested by the GWPP Manager (or authorized designee). All sampling and related field activities (e.g., depth-to-water measurements) are performed in accordance with the methods described in the GWPP technical procedures, or functionally equivalent technical procedures used by other organizations responsible for implementation of the regulatory monitoring programs at Y-12.

Historically, all groundwater samples collected by the GWPP were analyzed for a comprehensive suite of analytes referred to as the Standard Administrative Parameter Group. Beginning in CY 2009, a reduced list of analytes, referred to as selective parameter monitoring (SPM), is performed on samples from a subset of monitoring wells with analytical results for at least eight samples obtained since January 1991. For wells to qualify for SPM, the historical data must: (1) clearly demonstrate that the selected parameters are the contaminants of concern, and (2) provide sufficient data for the other parameters without additional analyses. The SPM analytes for each selected well are based on analytical methods and are designed to obtain the data necessary to meet requirements of the GWPP monitoring program. The wells selected for SPM may be analyzed for the Standard Administrative Parameter Group at various intervals to verify that current concentrations of other analytes reflect historical data, or to meet programmatic requirements of the GWPP.

\subsection{INSPECTION AND MAINTENANCE}

Groundwater monitoring wells at Y-12 are regularly inspected and actively maintained to ensure that they continue to yield representative hydrologic and groundwater quality monitoring data. The active or inactive status designation for each well determines the frequency at which the GWPP will inspect the applicable wells, the scope of these inspections, and the extent of maintenance response actions. Inspection and maintenance activities will be performed in accordance with the most recent version of the $Y-12$ GWPP Monitoring Well Inspection and Maintenance Plan (BWXT 2006b), which applies only to the wells for which B\&W Y-12 assumes organizational responsibility under the GWPP. Other organizations retain responsibility for the wells that are used for RCRA-, CERCLA-, and SWDF-related groundwater monitoring, with 
respective inspection and maintenance requirements defined and/or referenced in the PCP for each hydrogeologic regime, the applicable CERCLA decision documents and related technical reports, and the operating permit or post-closure plan for the corresponding SWDF (see Section 2.1).

Wells granted active status under the GWPP will be inspected annually. During each inspection, the security status (locked or unlocked well cap) of each well will be verified and the applicable above-ground components of the each well (identification tag, cap, lock hasp, lock, concrete pad, and protective posts) will be assessed for visible damage, deterioration, and functionality. All-weather access to each well also will be evaluated during the annual inspection. Every three years, as a qualitative check on down-hole conditions in each well, the total depth to the bottom of the well will be measured and compared to the Reference Tag Depth for the well (B\&W Y-12 2008). Based on the outcome of each inspection, the GWPP Manager will initiate the necessary and appropriate maintenance actions needed to ensure the access, security, physical condition, and performance of the applicable well(s).

Wells granted inactive status under the GWPP will be inspected once every three years. During each inspection, the security status of each well will be verified; the applicable above-ground components of each well will be assessed for visible damage, deterioration, and functionality; and the total depth to the bottom of each well will be measured and compared to the Reference Tag Depth for the well (B\&W Y-12 2008). Based on the outcome of each inspection, the GWPP Manager will initiate only those maintenance actions needed to ensure the security and identification of each well, such as replacement of inoperable well locks and identification tags. 


\subsection{REFERENCES}

Babcock \& Wilcox Technical Services Y-12, LLC (B\&W Y-12). 2008. Y-12 Groundwater Protection Program CY 2006 Triennial Report of the Monitoring Well Inspection and Maintenance Program, Y-12 National Security Complex, Oak Ridge, Tennessee. Prepared by the Y-12 Environment, Safety, and Health Division (Y/TS-2117).

B\&W Y-12. 2009a. Groundwater Protection Program Management Plan for the U.S. Department of Energy Y-12 National Security Complex, Oak Ridge, Tennessee. Prepared by Elvado Environmental LLC. (Y/SUB/01-006512/2/R2).

B\&W Y-12. 2009b. Supplemental Assessment of the Y-12 Groundwater Protection Program Using Monitoring and Remediation Optimization System Software. Prepared by Elvado Environmental LLC and GSI Environmental, Inc. (Y/TS-2118).

Bechtel Jacobs Company LLC. 2009. Addendum to Bechtel Jacobs Company LLC Sampling and Analysis Plan for the Water Resources Restoration Program for Fiscal Year 2009, Oak Ridge Reservation, Oak Ridge, Tennessee. (BJC/OR-3121, R0/A1).

BWXT Y-12 L.L.C. 2003. Updated Subsurface Data Base for Bear Creek Valley, Chestnut Ridge, and Parts of Bethel Valley on the U.S. Department of Energy Oak Ridge Reservation. Prepared by the Y-12 Environment, Safety, and Health Division (Y/TS-881/R5).

BWXT Y-12 L.L.C. 2005. Assessment of the Groundwater Protection Program, Y-12 National Security Complex, Oak Ridge, Tennessee. Prepared by Groundwater Services, Inc. (Y/TS-1984)

BWXT Y-12 L.L.C. 2006a. Y-12 Groundwater Protection Program Data Management Plan, Revision 3. Prepared by Science Applications International Corporation (Y/TS-2007).

BWXT Y-12 L.L.C. 2006b. Monitoring Well Inspection and Maintenance Plan, Y-12 Plant, Oak Ridge, Tennessee, Revision 3. Prepared by the Y-12 Environment, Safety, and Health Organization (Y/TS1215).

Lockheed Martin Energy Systems, Inc. 1997. Monitoring Well Installation Plan for the Department of Energy Y-12 Plant, Oak Ridge, Tennessee. Prepared by Science Applications International Corporation (Y/SUB/00-KFX63/C/1).

U.S. Department of Energy. 2006. Ground Water Surveillance Monitoring Implementation Guide for Use with DOE Order 450.1, Environmental Protection Program. U.S. Department of Energy, Washington, DC (DOE G 450.1-6). 
APPENDIX A

\section{FIGURES}




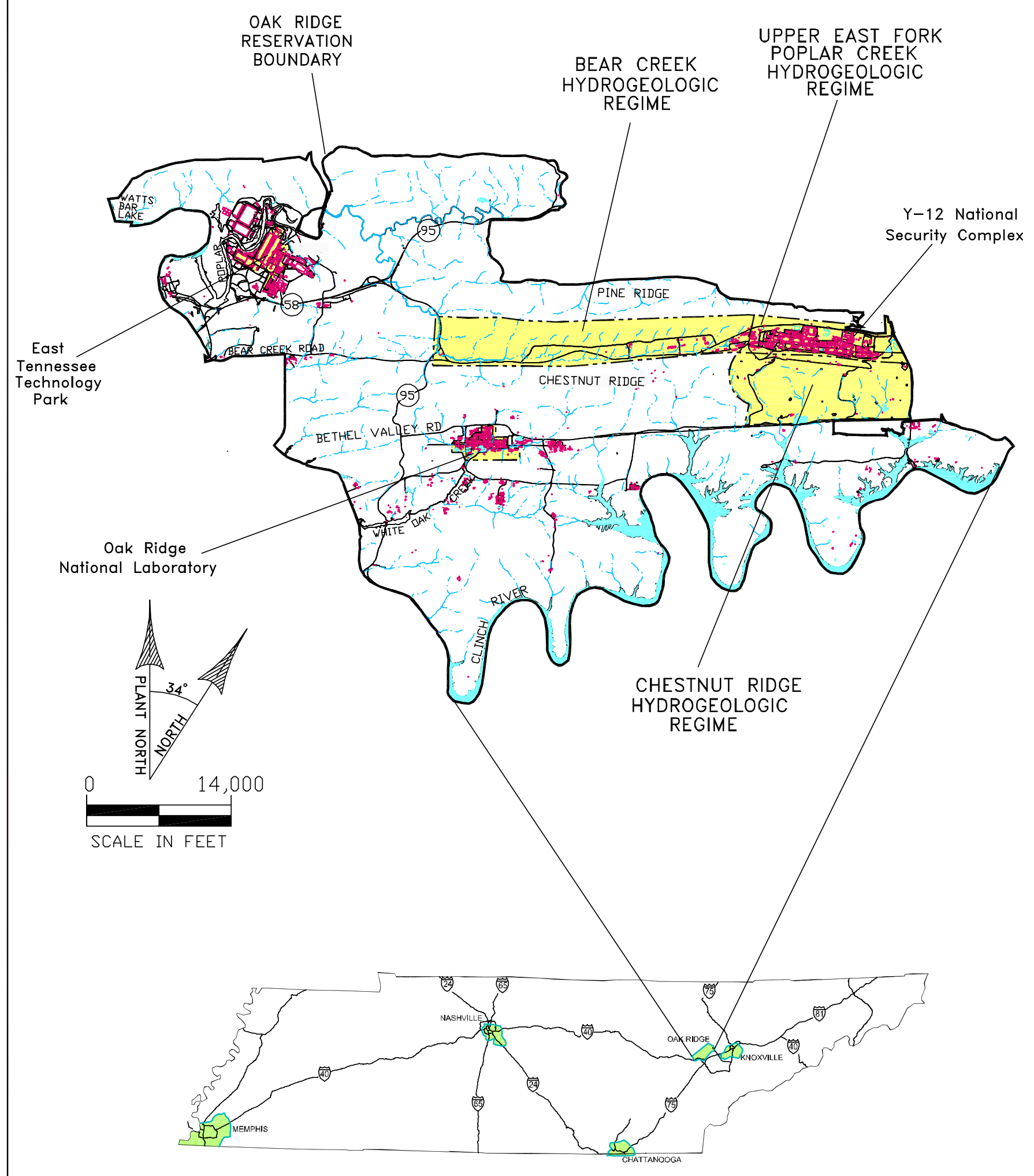

GWPP Fig1 09/23/08

Fig. A.1. Hydrogeologic regimes at the Y-12 National Security Complex. 


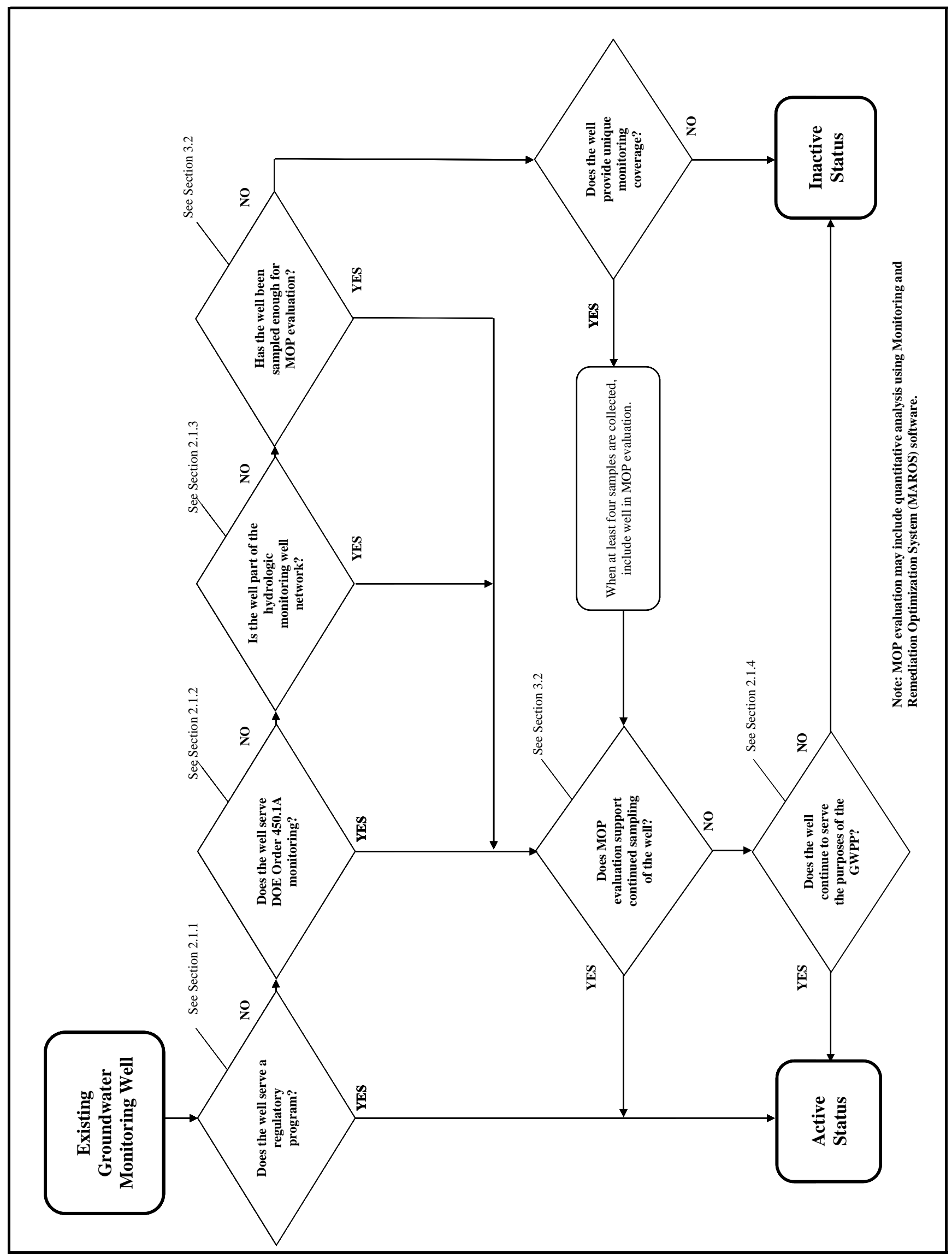

Fig. A.2. Process used to designate the status of groundwater monitoring wells at the Y-12 National Security Complex. 


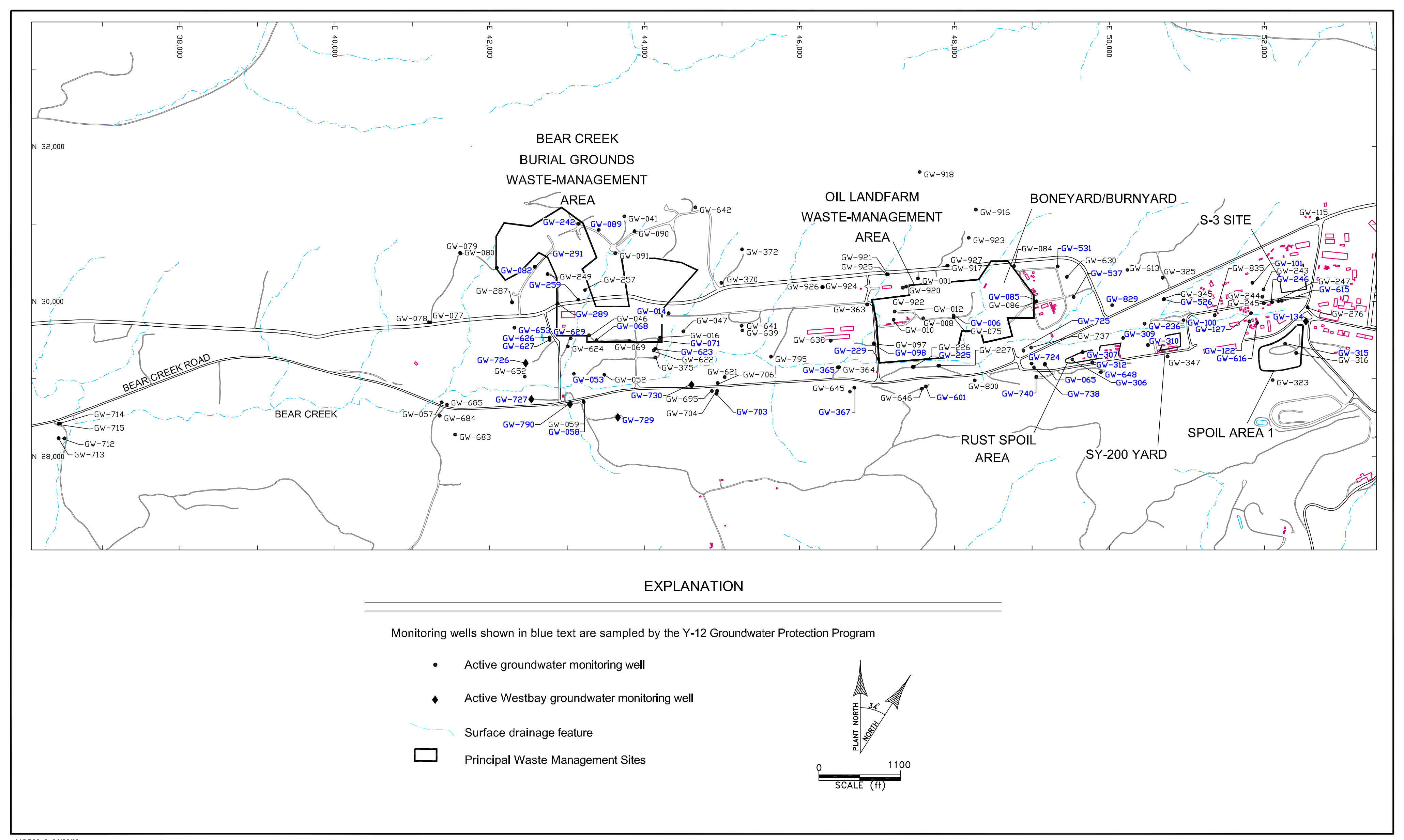




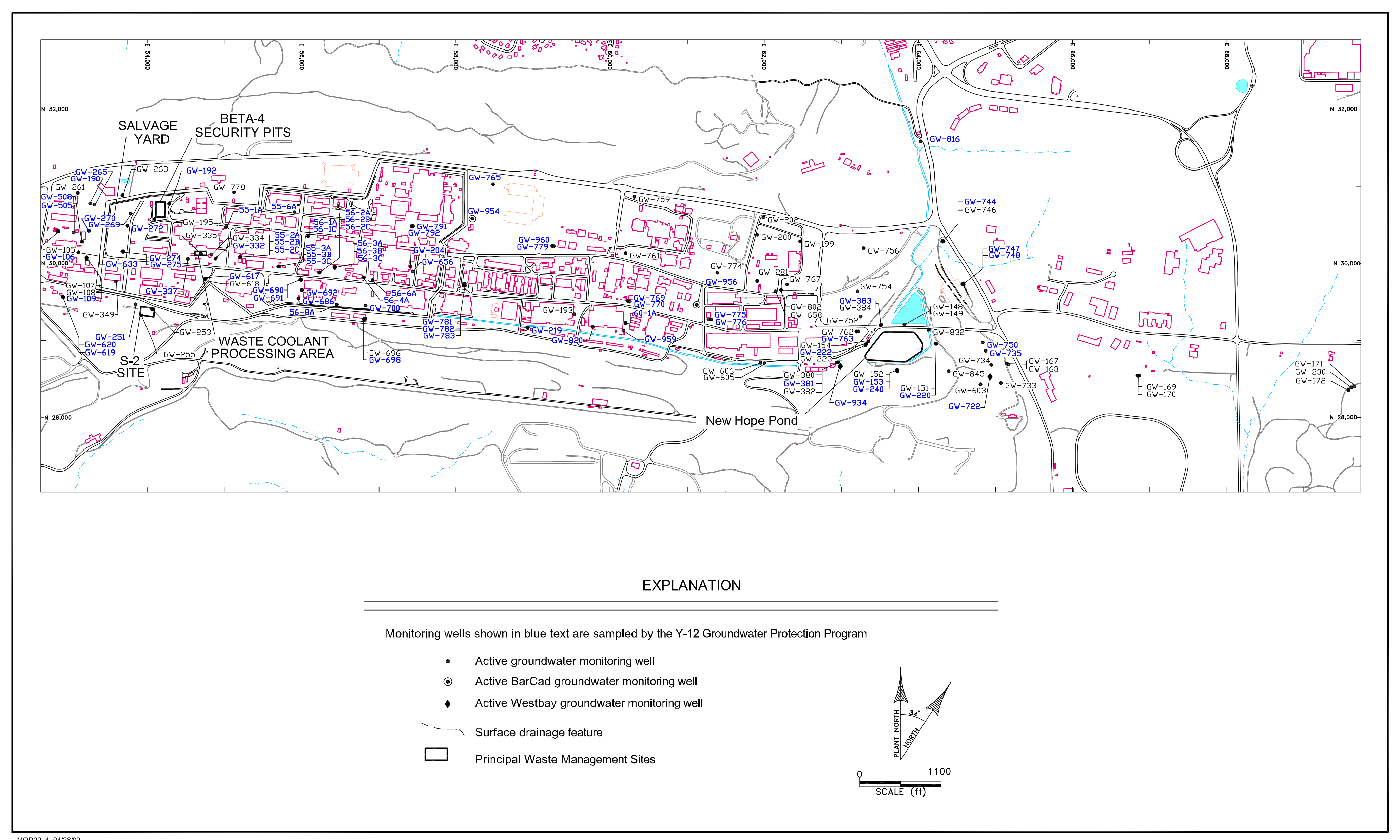




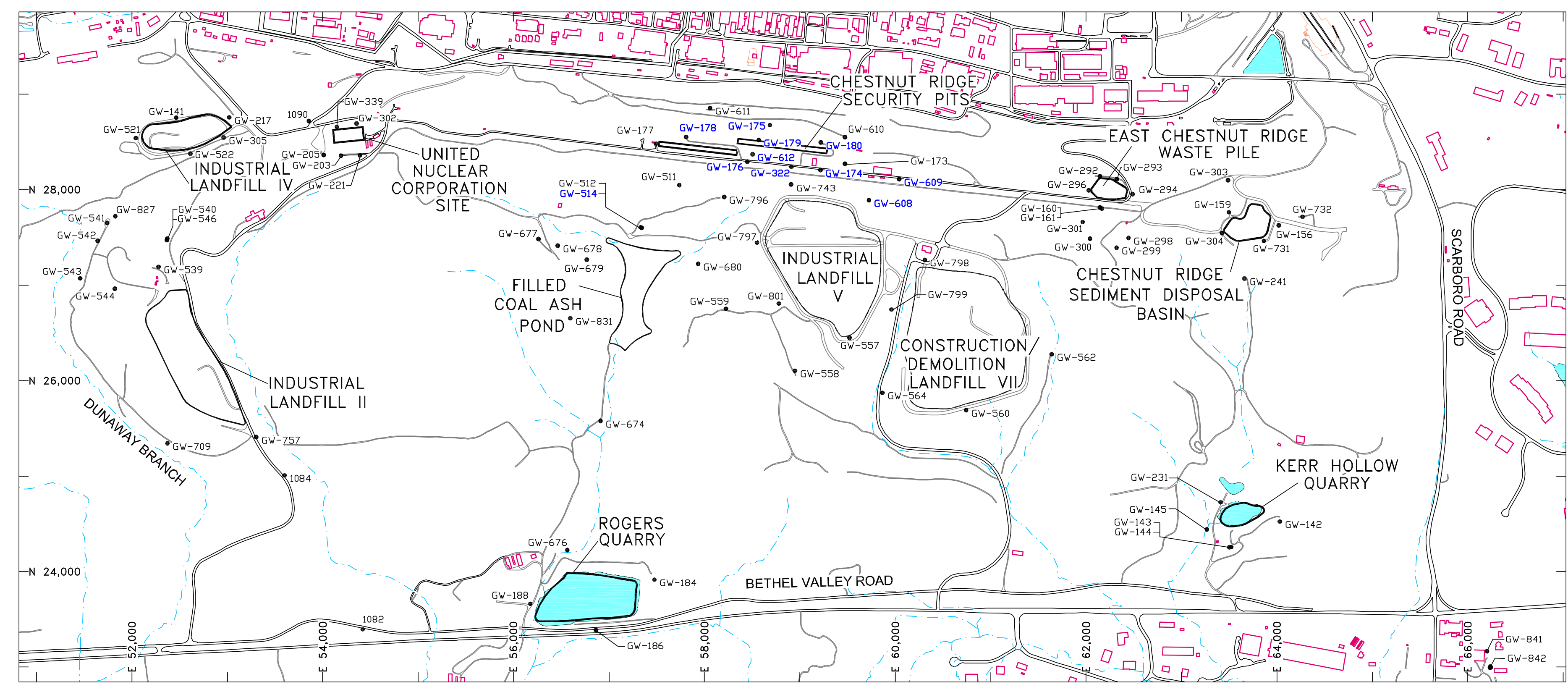

EXPLANATION

Monitoring wells shown in blue text are sampled by the $\mathrm{Y}-12$ Groundwater Protection Program

- Active groundwater monitoring well

-.. Surface drainage feature

$\square \quad$ Principal Waste Management Sites
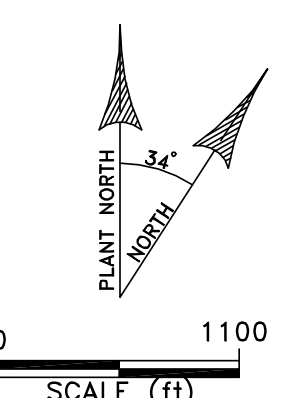
APPENDIX B

TABLES 
Table B.1. Groundwater monitoring wells that are granted active status under the Y-12 Groundwater Protection Program

\begin{tabular}{|c|c|c|c|c|c|c|c|c|c|c|c|c|}
\hline \multirow{3}{*}{ Well } & \multirow{3}{*}{ Regime $^{1}$} & \multicolumn{3}{|c|}{ Active Status Criteria } & \multirow{3}{*}{$\begin{array}{c}\text { GWPP } \\
\text { Sampling }^{\text {Frequency }}{ }^{3}\end{array}$} & \multicolumn{6}{|c|}{ Monitoring Criteria } & \multirow{3}{*}{$\begin{array}{c}\text { Supplemental } \\
\text { MAROS } \\
\text { Evaluation }^{6}\end{array}$} \\
\hline & & \multirow{2}{*}{$\begin{array}{c}\text { Reg. }^{2} \\
\text { Program }\end{array}$} & \multirow{2}{*}{$\begin{array}{c}\text { Hydro- } \\
\text { logic }\end{array}$} & \multirow{2}{*}{$\begin{array}{c}\text { DOE } \\
\text { Order }\end{array}$} & & \multicolumn{5}{|c|}{ Contamination ${ }^{4}$} & \multirow{2}{*}{$\begin{array}{l}\text { Unique } \\
\text { Char. }{ }^{5}\end{array}$} & \\
\hline & & & & & & $\mathbf{N}$ & $\mathbf{U}$ & $\mathbf{V}$ & $\mathbf{A}$ & B & & \\
\hline 1082 & CR & & $\bar{X}$ & & & & & & & & & \\
\hline 1084 & CR & & $\mathrm{X}$ & & & & & & & & & \\
\hline 1090 & CR & $\mathrm{C}$ & $\mathrm{X}$ & & & & & & & & & \\
\hline $55-1 \mathrm{~A}$ & $\mathrm{EF}$ & & $\mathrm{X}$ & $\mathrm{X}$ & 2013 & $\mathrm{X}$ & & & & & & Every 5 years \\
\hline $55-2 \mathrm{~A}$ & $\mathrm{EF}$ & & & $\mathrm{X}$ & Odd & $X$ & & $X$ & & & & Biennial \\
\hline $55-2 B$ & $\mathrm{EF}$ & & & $\mathrm{X}$ & Annual & $\mathrm{X}$ & & $\mathrm{X}$ & & & & Annual \\
\hline $55-2 \mathrm{C}$ & $\mathrm{EF}$ & & & $\mathrm{X}$ & Annual & $\mathrm{X}$ & & $\mathrm{X}$ & & & & Annual \\
\hline $55-3 \mathrm{~A}$ & $\mathrm{EF}$ & & $\mathrm{X}$ & $\mathrm{X}$ & Semiannual & & & $\mathrm{X}$ & & & & Semiannual \\
\hline $55-3 \mathrm{~B}$ & $\mathrm{EF}$ & & & $\mathrm{X}$ & Semiannual & & & $\mathrm{X}$ & & & & Semiannual \\
\hline $55-3 C$ & $\mathrm{EF}$ & & & $\mathrm{X}$ & Semiannual & & & $\mathrm{X}$ & & & & Semiannual \\
\hline $55-6 \mathrm{~A}$ & $\mathrm{EF}$ & & $\mathrm{X}$ & $\mathrm{X}$ & 2013 & & & & & & $\mathrm{X}$ & - \\
\hline $56-1 \mathrm{~A}$ & $\mathrm{EF}$ & & $\mathrm{X}$ & $\mathrm{X}$ & Annual & & & & & & $\mathrm{X}$ & Annual \\
\hline $56-1 \mathrm{C}$ & $\mathrm{EF}$ & & & $\mathrm{X}$ & Annual & & & & & & $\mathrm{X}$ & - \\
\hline $56-2 \mathrm{~A}$ & $\mathrm{EF}$ & & $\mathrm{X}$ & $\mathrm{X}$ & Annual & & & $\mathrm{X}$ & & & & Annual \\
\hline $56-2 B$ & $\mathrm{EF}$ & & & $\mathrm{X}$ & Annual & & & $\mathrm{X}$ & & & & Annual \\
\hline $56-2 \mathrm{C}$ & $\mathrm{EF}$ & & & $\mathrm{X}$ & Annual & & & $\mathrm{X}$ & & & & Annual \\
\hline $56-3 \mathrm{~A}$ & $\mathrm{EF}$ & & & $\mathrm{X}$ & Annual & & & $\mathrm{X}$ & & & & Annual \\
\hline $56-3 \mathrm{~B}$ & $\mathrm{EF}$ & & & $\mathrm{X}$ & Annual & & & $\mathrm{X}$ & & & & Annual \\
\hline $56-3 \mathrm{C}$ & $\mathrm{EF}$ & & & $\mathrm{X}$ & Annual & & & $\mathrm{X}$ & & & & Annual \\
\hline $56-4 \mathrm{~A}$ & $\mathrm{EF}$ & & & $\mathrm{X}$ & Annual & & & $\mathrm{X}$ & & & & Annual \\
\hline $56-6 \mathrm{~A}$ & $\mathrm{EF}$ & & & $\mathrm{X}$ & Even & & & & & & $\mathrm{X}$ & Biennial \\
\hline $56-8 \mathrm{~A}$ & $\mathrm{EF}$ & & $\mathrm{X}$ & $\mathrm{X}$ & Even & & & $\mathrm{X}$ & & & & Annual \\
\hline $60-1 \mathrm{~A}$ & $\mathrm{EF}$ & & $\mathrm{X}$ & $\mathrm{X}$ & Even & & & & & & $\mathrm{X}$ & Biennial \\
\hline GW-001 & $\mathrm{BC}$ & & $\mathrm{X}$ & & & & & & & & & \\
\hline GW-006 & $\mathrm{BC}$ & & & $\mathrm{X}$ & Even & & & $\mathrm{X}$ & & & & Biennial \\
\hline GW-008 & BC & $\mathrm{R}$ & $\mathrm{X}$ & & & & & & & & & \\
\hline GW-010 & $\mathrm{BC}$ & $\mathrm{R} *$ & $\mathrm{X}$ & & & & & & & & & \\
\hline GW-012 & $\mathrm{BC}$ & $\mathrm{R}^{*}$ & $\mathrm{X}$ & & & & & & & & & \\
\hline GW-014 & $\mathrm{BC}$ & $\mathrm{R} *$ & $\mathrm{X}$ & $\mathrm{X}$ & Annual & & & $\mathrm{X}$ & & & & Semiannual \\
\hline GW-016 & $\mathrm{BC}$ & & $\mathrm{X}$ & & & & & & & & & \\
\hline GW-041 & $\mathrm{BC}$ & & $\mathrm{X}$ & & & & & & & & & \\
\hline GW-046 & $\mathrm{BC}$ & $\mathrm{R}$ & $\mathrm{X}$ & & & & & & & & & \\
\hline GW-047 & $\mathrm{BC}$ & & $\mathrm{X}$ & & & & & & & & & \\
\hline GW-052 & BC & & $\mathrm{X}$ & & & & & & & & & \\
\hline GW-053 & $\mathrm{BC}$ & & $\mathrm{X}$ & $\mathrm{X}$ & Odd & & & $\mathrm{X}$ & & & & Biennial \\
\hline GW-057 & $\mathrm{BC}$ & & $\mathrm{X}$ & & & & & & & & & \\
\hline GW-058 & $\mathrm{BC}$ & & & $\mathrm{X}$ & Odd & & $X$ & & $X$ & & & Biennial \\
\hline GW-059 & $\mathrm{BC}$ & & $\mathrm{X}$ & & & & & & & & & \\
\hline GW-065 & BC & & $\mathrm{X}$ & $\mathrm{X}$ & Semiannual & & & & & & $\mathrm{X}$ & - \\
\hline GW-068 & $\mathrm{BC}$ & & & $\mathrm{X}$ & Annual & & & $\mathrm{X}$ & & & & Semiannual \\
\hline GW-069 & $\mathrm{BC}$ & $\mathrm{R}^{*}$ & $\mathrm{X}$ & & & & & & & & & \\
\hline GW-071 & $\mathrm{BC}$ & $\mathrm{R}^{*}$ & & $\mathrm{X}$ & Semiannual & & & $\mathrm{X}$ & & & & Semiannual \\
\hline GW-075 & BC & $\mathrm{R} *$ & & & & & & & & & & \\
\hline GW-077 & $\mathrm{BC}$ & C & & & & & & & & & & \\
\hline GW-078 & $\mathrm{BC}$ & $\mathrm{C}$ & $\mathrm{X}$ & & & & & & & & & \\
\hline GW-079 & $\mathrm{BC}$ & C & & & & & & & & & & \\
\hline GW-080 & $\mathrm{BC}$ & C & $\mathrm{X}$ & & & & & & & & & \\
\hline GW-082 & $\mathrm{BC}$ & $\mathrm{R} *$ & $\mathrm{X}$ & $\mathrm{X}$ & Annual & & & $\mathrm{X}$ & & & & Annual \\
\hline GW-084 & $\mathrm{BC}$ & & $\mathrm{X}$ & & & & & & & & & \\
\hline GW-085 & $\mathrm{BC}$ & & & $\mathrm{X}$ & Annual & $\mathrm{X}$ & & & & $\mathrm{X}$ & & Annual \\
\hline GW-086 & BC & & $\mathrm{X}$ & & & & & & & & & \\
\hline
\end{tabular}


Table B.1 (continued)

\begin{tabular}{|c|c|c|c|c|c|c|c|c|c|c|c|c|}
\hline \multirow{3}{*}{ Well } & \multirow{3}{*}{ Regime $^{1}$} & \multicolumn{3}{|c|}{ Active Status Criteria } & \multirow{3}{*}{$\begin{array}{c}\text { GWPP } \\
\text { Sampling } \\
\text { Frequency }^{3}\end{array}$} & \multicolumn{6}{|c|}{ Monitoring Criteria } & \multirow{3}{*}{$\begin{array}{c}\text { Supplemtal } \\
\text { MAROS } \\
\text { Evaluation }^{6}\end{array}$} \\
\hline & & \multirow{2}{*}{$\begin{array}{c}\text { Reg. }^{2} \\
\text { Program }\end{array}$} & \multirow{2}{*}{$\begin{array}{c}\text { Hydro- } \\
\text { logic }\end{array}$} & \multirow{2}{*}{$\begin{array}{l}\text { DOE } \\
\text { Order }\end{array}$} & & \multicolumn{5}{|c|}{ Contamination $^{4}$} & \multirow{2}{*}{$\begin{array}{c}\text { Unique } \\
\text { Char. }^{5}\end{array}$} & \\
\hline & & & & & & $\mathbf{N}$ & $\mathbf{U}$ & $\mathbf{V}$ & $\mathbf{A}$ & $\mathbf{B}$ & & \\
\hline GW-089 & $\mathrm{BC}$ & & & $\mathrm{X}$ & 2013 & & & $\mathrm{X}$ & & & & Eliminate \\
\hline GW-090 & $\mathrm{BC}$ & & $\mathrm{X}$ & & & & & & & & & \\
\hline GW-091 & $\mathrm{BC}$ & & $\mathrm{X}$ & & & & & & & & & \\
\hline GW-097 & $\mathrm{BC}$ & & $\mathrm{X}$ & & & & & & & & & \\
\hline GW-098 & $\mathrm{BC}$ & & & $\mathrm{X}$ & Annual & & & $\mathrm{X}$ & & & & Annual \\
\hline GW-100 & $\mathrm{BC}$ & & $\mathrm{X}$ & $\mathrm{X}$ & Annual & $\mathrm{X}$ & & & & & & Annual \\
\hline GW-101 & $\mathrm{BC}$ & $\mathrm{R}^{*}$ & $\mathrm{X}$ & $\mathrm{X}$ & Annual & $\mathrm{X}$ & & & & & & Annual \\
\hline GW-105 & $\mathrm{EF}$ & & $\mathrm{X}$ & & & & & & & & & \\
\hline GW-106 & $\mathrm{EF}$ & & & $\mathrm{X}$ & Even & $\mathrm{X}$ & & & & & & Biennial \\
\hline GW-107 & $\mathrm{EF}$ & & $\mathrm{X}$ & & & & & & & & & \\
\hline GW-108 & $\mathrm{EF}$ & $\mathrm{R}$ & $\mathrm{X}$ & & & & & & & & & \\
\hline GW-109 & $\mathrm{EF}$ & $\mathrm{R} *$ & & $\mathrm{X}$ & Even & $X$ & & $X$ & & $\mathrm{X}$ & & Biennial \\
\hline GW-115 & $\mathrm{BC}$ & & $\mathrm{X}$ & & & & & & & & & \\
\hline GW-122 & $\mathrm{BC}$ & & & $\mathrm{X}$ & Odd & $\mathrm{X}$ & & & & & & Eliminate \\
\hline GW-127 & $\mathrm{BC}$ & $\mathrm{R}^{*}$ & $\mathrm{X}$ & $\mathrm{X}$ & Odd & & & & & & $\mathrm{X}$ & Eliminate \\
\hline GW-134 & $\mathrm{BC}$ & & & $\mathrm{X}$ & TBD & $\mathrm{X}$ & & $\mathrm{X}$ & & $\mathrm{X}$ & WB (10) & - \\
\hline GW-141 & CR & $\mathrm{S}$ & $\mathrm{X}$ & & & & & & & & & \\
\hline GW-142 & CR & & $\mathrm{X}$ & & & & & & & & & \\
\hline GW-143 & CR & $\mathrm{R} / \mathrm{C}$ & & & & & & & & & & \\
\hline GW-144 & CR & $\mathrm{R} / \mathrm{C}$ & $\mathrm{X}$ & & & & & & & & & \\
\hline GW-145 & CR & $\mathrm{R} / \mathrm{C}$ & $\mathrm{X}$ & & & & & & & & & \\
\hline GW-148 & $\mathrm{EF}$ & & $\mathrm{X}$ & $\mathrm{X}$ & Even & & & $\mathrm{X}$ & & & & Biennial \\
\hline GW-149 & $\mathrm{EF}$ & C (wl) & & & & & & & & & & \\
\hline GW-151 & $\mathrm{EF}$ & C & $\mathrm{X}$ & & & & & & & & & \\
\hline GW-152 & $\mathrm{EF}$ & C & $\mathrm{X}$ & & & & & & & & & \\
\hline GW-153 & $\mathrm{EF}$ & C & & $\mathrm{X}$ & Annual & & & $\mathrm{X}$ & & & & - \\
\hline GW-154 & $\mathrm{EF}$ & C & $\mathrm{X}$ & & & & & & & & & \\
\hline GW-156 & CR & $\mathrm{R}$ & $\mathrm{X}$ & & & & & & & & & \\
\hline GW-159 & CR & $\mathrm{R}$ & $\mathrm{X}$ & & & & & & & & & \\
\hline GW-160 & CR & & $\mathrm{X}$ & & & & & & & & & \\
\hline GW-161 & CR & $\mathrm{R}$ & & & & & & & & & & \\
\hline GW-167 & EF & & $\mathrm{X}$ & & & & & & & & & \\
\hline GW-168 & $\mathrm{EF}$ & $\mathrm{C}(\mathrm{wl})$ & & & & & & & & & & \\
\hline GW-169 & EF & C & $\mathrm{X}$ & & & & & & & & & \\
\hline GW-170 & $\mathrm{EF}$ & $\mathrm{C}$ & & & & & & & & & & \\
\hline GW-171 & $\mathrm{EF}$ & $\mathrm{C}$ & & & & & & & & & & \\
\hline GW-172 & $\mathrm{EF}$ & $\mathrm{C}$ & & & & & & & & & & \\
\hline GW-173 & CR & & $\mathrm{X}$ & & & & & & & & & \\
\hline GW-174 & CR & & $\mathrm{X}$ & $\mathrm{X}$ & Odd & & & $\mathrm{X}$ & & & & Biennial \\
\hline GW-175 & CR & $\mathrm{R} *$ & $\mathrm{X}$ & $\mathrm{X}$ & Odd & & & $\mathrm{X}$ & & & & Biennial \\
\hline GW-176 & CR & & $\mathrm{X}$ & $\mathrm{X}$ & Odd & & & $\mathrm{X}$ & & & & Biennial \\
\hline GW-177 & CR & $\mathrm{R}$ & $\mathrm{X}$ & & & & & & & & & \\
\hline GW-178 & CR & & $\mathrm{X}$ & $\mathrm{X}$ & 2013 & & & $\mathrm{X}$ & & & & Every 5 years \\
\hline GW-179 & CR & & $\mathrm{X}$ & $\mathrm{X}$ & 2012 & & & $\mathrm{X}$ & & & & Every 5 years \\
\hline GW-180 & CR & & $\mathrm{X}$ & $\mathrm{X}$ & Odd & & & $\mathrm{X}$ & & & & Biennial \\
\hline GW-184 & CR & & $\mathrm{X}$ & & & & & & & & & \\
\hline GW-186 & CR & & $\mathrm{X}$ & & & & & & & & & \\
\hline GW-188 & CR & & $\mathrm{X}$ & & & & & & & & & \\
\hline GW-190 & $\mathrm{EF}$ & & & $\mathrm{X}$ & 2013 & & & & & & $\mathrm{X}$ & Every 5 years \\
\hline GW-192 & EF & & $\mathrm{X}$ & $\mathrm{X}$ & 2013 & & & $\mathrm{X}$ & & & & Every 5 years \\
\hline GW-193 & $\mathrm{EF}$ & $\mathrm{R}$ & $\mathrm{X}$ & & & & & & & & & \\
\hline GW-195 & $\mathrm{EF}$ & & $\mathrm{X}$ & & & & & & & & & \\
\hline
\end{tabular}


Table B.1 (continued)

\begin{tabular}{|c|c|c|c|c|c|c|c|c|c|c|c|c|}
\hline \multirow{3}{*}{ Well } & \multirow{3}{*}{ Regime $^{1}$} & \multicolumn{3}{|c|}{ Active Status Criteria } & \multirow{3}{*}{$\begin{array}{c}\text { GWPP } \\
\text { Sampling } \\
\text { Frequency }^{3}\end{array}$} & \multicolumn{6}{|c|}{ Monitoring Criteria } & \multirow{3}{*}{$\begin{array}{c}\text { Supplemtal } \\
\text { MAROS } \\
\text { Evaluation }^{6}\end{array}$} \\
\hline & & \multirow{2}{*}{$\begin{array}{c}\text { Reg. }^{2} \\
\text { Program }\end{array}$} & \multirow{2}{*}{$\begin{array}{c}\text { Hydro- } \\
\text { logic }\end{array}$} & \multirow{2}{*}{$\begin{array}{l}\text { DOE } \\
\text { Order }\end{array}$} & & \multicolumn{5}{|c|}{ Contamination $^{4}$} & \multirow{2}{*}{$\begin{array}{c}\text { Unique } \\
\text { Char. }^{5}\end{array}$} & \\
\hline & & & & & & $\mathbf{N}$ & $\mathbf{U}$ & $\mathbf{V}$ & $\mathbf{A}$ & B & & \\
\hline GW-199 & $\mathrm{EF}$ & & $\mathrm{X}$ & & & & & & & & & \\
\hline GW-200 & $\mathrm{EF}$ & & $\mathrm{X}$ & & & & & & & & & \\
\hline GW-202 & EF & & $\mathrm{X}$ & & & & & & & & & \\
\hline GW-203 & CR & $\mathrm{C}$ & $\mathrm{X}$ & & & & & & & & & \\
\hline GW-204 & $\mathrm{EF}$ & & $\mathrm{X}$ & $\mathrm{X}$ & Annual & & $\mathrm{X}$ & & $\mathrm{X}$ & $\mathrm{X}$ & & Biennial \\
\hline GW-205 & CR & C & $\mathrm{X}$ & & & & & & & & & \\
\hline GW-217 & CR & $\mathrm{S}$ & $\mathrm{X}$ & & & & & & & & & \\
\hline GW-219 & $\mathrm{EF}$ & $\mathrm{C}$ & $\mathrm{X}$ & $\mathrm{X}$ & Odd & & $X$ & & $X$ & $X$ & & - \\
\hline GW-220 & $\mathrm{EF}$ & $\mathrm{C}$ & & $\mathrm{X}$ & Semiannual & & & $\mathrm{X}$ & & & & - \\
\hline GW-221 & CR & $\mathrm{C}$ & $\mathrm{X}$ & & & & & & & & & \\
\hline GW-222 & $\mathrm{EF}$ & & & $\mathrm{X}$ & $2009 / 2014$ & & $\mathrm{X}$ & $X$ & $\mathrm{X}$ & & & Annual \\
\hline GW-223 & $\mathrm{EF}$ & $\mathrm{C}$ & & & & & $X$ & $X$ & $X$ & & & \\
\hline GW-225 & $\mathrm{BC}$ & & & $\mathrm{X}$ & Annual & $\mathrm{X}$ & & $X$ & & & & Semiannual \\
\hline GW-226 & $\mathrm{BC}$ & & $\mathrm{X}$ & & & & & & & & & \\
\hline GW-227 & $\mathrm{BC}$ & & $\mathrm{X}$ & & & & & & & & & \\
\hline GW-229 & $\mathrm{BC}$ & & $\mathrm{X}$ & $\mathrm{X}$ & Annual & & $X$ & $X$ & $X$ & $X$ & & Annual \\
\hline GW-230 & EF & $\mathrm{C}$ & & & & & & & & & & \\
\hline GW-231 & CR & $\mathrm{R} / \mathrm{C}$ & $\mathrm{X}$ & & & & & & & & & \\
\hline GW-236 & $\mathrm{BC}$ & & $\mathrm{X}$ & $\mathrm{X}$ & Odd & $\mathrm{X}$ & & & & $X$ & & Eliminate \\
\hline GW-240 & EF & & & $\mathrm{X}$ & Annual & & & $X$ & & & & Annual \\
\hline GW-241 & CR & & $\mathrm{X}$ & & & & & & & & & \\
\hline GW-242 & $\mathrm{BC}$ & & $\mathrm{X}$ & $\mathrm{X}$ & Odd & & & $\mathrm{X}$ & & & & Annual \\
\hline GW-243 & BC & $\mathrm{R}^{*}$ & & & & & & & & & & \\
\hline GW-244 & $\mathrm{BC}$ & $\mathrm{R} *$ & & & & & & & & & & \\
\hline GW-245 & $\mathrm{BC}$ & $\mathrm{R}$ * & $\mathrm{X}$ & & & & & & & & & \\
\hline GW-246 & $\mathrm{BC}$ & $\mathrm{R} *$ & & $\mathrm{X}$ & Annual & $\mathrm{X}$ & $\mathrm{X}$ & $\mathrm{X}$ & $\mathrm{X}$ & $\mathrm{X}$ & & Annual \\
\hline GW-247 & $\mathrm{BC}$ & $\mathrm{R}^{*}$ & & & & & & & & & & \\
\hline GW-249 & $\mathrm{BC}$ & & $\mathrm{X}$ & & & & & & & & & \\
\hline GW-251 & EF & & $\mathrm{X}$ & $\mathrm{X}$ & Annual & $\mathrm{X}$ & & $X$ & & & & Annual \\
\hline GW-253 & EF & $\mathrm{R} / \mathrm{C}$ & $\mathrm{X}$ & & & & & & & & & \\
\hline GW-255 & $\mathrm{EF}$ & & $\mathrm{X}$ & & & & & & & & & \\
\hline GW-257 & $\mathrm{BC}$ & $\mathrm{R} *$ & $\mathrm{X}$ & & & & & & & & & \\
\hline GW-259 & $\mathrm{BC}$ & & & $\mathrm{X}$ & 2013 & & & $\mathrm{X}$ & & & & Every 5 years \\
\hline GW-261 & EF & & $\mathrm{X}$ & & & & & & & & & \\
\hline GW-263 & EF & & $\mathrm{X}$ & & & & & & & & & \\
\hline GW-265 & $\mathrm{EF}$ & & & $\mathrm{X}$ & 2013 & & & $X$ & & & & Every 5 years \\
\hline GW-269 & $\mathrm{EF}$ & & & $\mathrm{X}$ & Annual & & & $X$ & & & & Every 5 years \\
\hline GW-270 & EF & & & $\mathrm{X}$ & Odd & $\mathrm{X}$ & & & & & & Eliminate \\
\hline GW-272 & $\mathrm{EF}$ & & & $\mathrm{X}$ & Odd & $\mathrm{X}$ & $\mathrm{X}$ & & & & $\mathrm{X}$ & Annual \\
\hline GW-274 & $\mathrm{EF}$ & $\mathrm{R} *$ & & $\mathrm{X}$ & Annual & $X$ & $X$ & & & $X$ & & Annual \\
\hline GW-275 & $\mathrm{EF}$ & $\mathrm{R} *$ & & $\mathrm{X}$ & Annual & $\mathrm{X}$ & & & & & & Annual \\
\hline GW-276 & $\mathrm{BC}$ & $\mathrm{R}$ & $\mathrm{X}$ & & & & & & & & & \\
\hline GW-281 & EF & $\mathrm{C}$ & & & & & & & & & & \\
\hline GW-287 & $\mathrm{BC}$ & & $\mathrm{X}$ & & & & & & & & & \\
\hline GW-289 & $\mathrm{BC}$ & $\mathrm{R} *$ & $\mathrm{X}$ & $\mathrm{X}$ & Annual & & & $X$ & & & & Annual \\
\hline GW-291 & $\mathrm{BC}$ & $\mathrm{R} *$ & $\mathrm{X}$ & $\mathrm{X}$ & 2010/2015 & & & $\mathrm{X}$ & & & & Eliminate \\
\hline GW-292 & CR & $\mathrm{R} *$ & $\mathrm{X}$ & & & & & & & & & \\
\hline GW-293 & CR & $\mathrm{R} *$ & & & & & & & & & & \\
\hline GW-294 & CR & $\mathrm{R}$ & & & & & & & & & & \\
\hline GW-296 & CR & $\mathrm{R}$ & & & & & & & & & & \\
\hline GW-298 & CR & $\mathrm{R}$ & $\mathrm{X}$ & & & & & & & & & \\
\hline GW-299 & CR & & $\mathrm{X}$ & & & & & & & & & \\
\hline
\end{tabular}


Table B.1 (continued)

\begin{tabular}{|c|c|c|c|c|c|c|c|c|c|c|c|c|}
\hline \multirow{3}{*}{ Well } & \multirow{3}{*}{ Regime $^{1}$} & \multicolumn{3}{|c|}{ Active Status Criteria } & \multirow{3}{*}{$\begin{array}{c}\text { GWPP } \\
\text { Sampling } \\
\text { Frequency }^{3}\end{array}$} & \multicolumn{6}{|c|}{ Monitoring Criteria } & \multirow{3}{*}{$\begin{array}{c}\text { Supplemtal } \\
\text { MAROS } \\
\text { Evaluation }^{6}\end{array}$} \\
\hline & & \multirow{2}{*}{$\begin{array}{c}\text { Reg. }^{2} \\
\text { Program }\end{array}$} & \multirow{2}{*}{$\begin{array}{c}\text { Hydro- } \\
\text { logic }\end{array}$} & \multirow{2}{*}{$\begin{array}{l}\text { DOE } \\
\text { Order }\end{array}$} & & \multicolumn{5}{|c|}{ Contamination $^{4}$} & \multirow{2}{*}{$\begin{array}{c}\text { Unique } \\
\text { Char. }^{5}\end{array}$} & \\
\hline & & & & & & $\mathbf{N}$ & $\mathbf{U}$ & $\overline{\mathbf{V}}$ & $\mathbf{A}$ & $\bar{B}$ & & \\
\hline GW-300 & $\mathrm{CR}$ & & $\mathrm{X}$ & & & & & & & & & \\
\hline GW-301 & CR & $\mathrm{R}$ & $\mathrm{X}$ & & & & & & & & & \\
\hline GW-302 & CR & & $\mathrm{X}$ & & & & & & & & & \\
\hline GW-303 & CR & & $\mathrm{X}$ & & & & & & & & & \\
\hline GW-304 & CR & & $\mathrm{X}$ & & & & & & & & & \\
\hline GW-305 & CR & $\mathrm{S} / \mathrm{C}$ & $\mathrm{X}$ & & & & & & & & & \\
\hline GW-306 & $\mathrm{BC}$ & & & $\mathrm{X}$ & 2013 & & & $\mathrm{X}$ & & & & Every 5 years \\
\hline GW-307 & $\mathrm{BC}$ & & $\mathrm{X}$ & $\mathrm{X}$ & Annual & & & $\mathrm{X}$ & & & & Annual \\
\hline GW-309 & $\mathrm{BC}$ & & $\mathrm{X}$ & $\mathrm{X}$ & 2013 & $\mathrm{X}$ & & $\mathrm{X}$ & & & & Every 5 years \\
\hline GW-310 & $\mathrm{BC}$ & & $\mathrm{X}$ & $\mathrm{X}$ & Even & & & $\mathrm{X}$ & & & & Annual \\
\hline GW-312 & $\mathrm{BC}$ & & & $\mathrm{X}$ & Even & & & $\mathrm{X}$ & & & & Annual \\
\hline GW-315 & $\mathrm{BC}$ & & & $\mathrm{X}$ & Annual & & & $\mathrm{X}$ & & & & Annual \\
\hline GW-316 & $\mathrm{BC}$ & & $\mathrm{X}$ & & & & & & & & & \\
\hline GW-322 & CR & & $\mathrm{X}$ & $\mathrm{X}$ & Annual & & & $\mathrm{X}$ & & & & Annual \\
\hline GW-323 & $\mathrm{BC}$ & & $\mathrm{X}$ & & & & & & & & & \\
\hline GW-325 & $\mathrm{BC}$ & & $\mathrm{X}$ & & & & & & & & & \\
\hline GW-332 & EF & & & $\mathrm{X}$ & Annual & & & $\mathrm{X}$ & & & & Annual \\
\hline GW-334 & $\mathrm{EF}$ & & $\mathrm{X}$ & & & & & & & & & \\
\hline GW-335 & $\mathrm{EF}$ & & $\mathrm{X}$ & & & & & & & & & \\
\hline GW-337 & $\mathrm{EF}$ & & & $\mathrm{X}$ & Annual & & & $\mathrm{X}$ & & & & Annual \\
\hline GW-339 & CR & & $\mathrm{X}$ & & & & & & & & & \\
\hline GW-345 & $\mathrm{BC}$ & & $\mathrm{X}$ & & & & & & & & & \\
\hline GW-347 & BC & & $\mathrm{X}$ & & & & & & & & & \\
\hline GW-349 & $\mathrm{EF}$ & & $\mathrm{X}$ & & & & & & & & & \\
\hline GW-363 & $\mathrm{BC}$ & $\mathrm{R} / \mathrm{C}$ & & & & & & & & & & \\
\hline GW-364 & $\mathrm{BC}$ & & $\mathrm{X}$ & & & & & & & & & \\
\hline GW-365 & $\mathrm{BC}$ & & & $\mathrm{X}$ & Annual & & & $\mathrm{X}$ & & & & Annual \\
\hline GW-367 & $\mathrm{BC}$ & & & $\mathrm{X}$ & 2013 & & & $\mathrm{X}$ & & & & Every 5 years \\
\hline GW-370 & $\mathrm{BC}$ & & $\mathrm{X}$ & & & & & & & & & \\
\hline GW-372 & $\mathrm{BC}$ & & $\mathrm{X}$ & & & & & & & & & \\
\hline GW-380 & $\mathrm{EF}$ & $\mathrm{C}$ & $\mathrm{X}$ & & & & & & & & & \\
\hline GW-381 & EF & $\mathrm{C}$ & & $\mathrm{X}$ & Annual & & & $\mathrm{X}$ & & & & - \\
\hline GW-382 & $\mathrm{EF}$ & $\mathrm{C}$ & & & & & & & & & & \\
\hline GW-383 & EF & $\mathrm{C}$ & $\mathrm{X}$ & $\mathrm{X}$ & Annual & & & $\mathrm{X}$ & & & & - \\
\hline GW-384 & $\mathrm{EF}$ & $\mathrm{C}(\mathrm{wl})$ & & & & & & & & & & \\
\hline GW-505 & $\mathrm{EF}$ & & & $\mathrm{X}$ & Odd & & & & $\mathrm{X}$ & & & Biennial \\
\hline GW-508 & $\mathrm{EF}$ & & & $\mathrm{X}$ & Odd & & & $\mathrm{X}$ & & & & Every 5 years \\
\hline GW-511 & CR & & $\mathrm{X}$ & & & & & & & & & \\
\hline GW-512 & CR & & $\mathrm{X}$ & & & & & & & & & \\
\hline GW-514 & CR & $\mathrm{R} *$ & & $\mathrm{X}$ & Even & & & & & & $\mathrm{X}$ & Biennial \\
\hline GW-521 & CR & $\mathrm{R} / \mathrm{S}$ & $\mathrm{X}$ & & & & & & & & & \\
\hline GW-522 & CR & $\mathrm{S}$ & $\mathrm{X}$ & & & & & & & & & \\
\hline GW-526 & $\mathrm{BC}$ & & & $\mathrm{X}$ & Annual & $\mathrm{X}$ & & & & & & Annual \\
\hline GW-531 & $\mathrm{BC}$ & & $\mathrm{X}$ & $\mathrm{X}$ & 2013 & & & & & & $\mathrm{X}$ & Eliminate \\
\hline GW-537 & $\mathrm{BC}$ & & $\mathrm{X}$ & $\mathrm{X}$ & Annual & $\mathrm{X}$ & & & & $\mathrm{X}$ & & Annual \\
\hline GW-539 & CR & & $\mathrm{X}$ & & & & & & & & & \\
\hline GW-540 & CR & $\mathrm{S}$ & & & & & & & & & & \\
\hline GW-541 & CR & & $\mathrm{X}$ & & & & & & & & & \\
\hline GW-542 & CR & & $\mathrm{X}$ & & & & & & & & & \\
\hline GW-543 & CR & & $\mathrm{X}$ & & & & & & & & & \\
\hline GW-544 & CR & & $\mathrm{X}$ & & & & & & & & & \\
\hline GW-546 & CR & & $\mathrm{X}$ & & & & & & & & & \\
\hline
\end{tabular}


Table B.1 (continued)

\begin{tabular}{|c|c|c|c|c|c|c|c|c|c|c|c|c|}
\hline \multirow{3}{*}{ Well } & \multirow{3}{*}{ Regime $^{1}$} & \multicolumn{3}{|c|}{ Active Status Criteria } & \multirow{3}{*}{$\begin{array}{c}\text { GWPP } \\
\text { Sampling } \\
\text { Frequency }^{3}\end{array}$} & \multicolumn{6}{|c|}{ Monitoring Criteria } & \multirow{3}{*}{$\begin{array}{c}\text { Supplemtal } \\
\text { MAROS } \\
\text { Evaluation }^{6}\end{array}$} \\
\hline & & \multirow{2}{*}{$\begin{array}{c}\text { Reg. }^{2} \\
\text { Program }\end{array}$} & \multirow{2}{*}{$\begin{array}{c}\text { Hydro- } \\
\text { logic }\end{array}$} & \multirow{2}{*}{$\begin{array}{l}\text { DOE } \\
\text { Order }\end{array}$} & & \multicolumn{5}{|c|}{ Contamination $^{4}$} & \multirow{2}{*}{$\begin{array}{c}\text { Unique } \\
\text { Char. }^{5}\end{array}$} & \\
\hline & & & & & & $\mathbf{N}$ & $\mathbf{U}$ & $\mathbf{V}$ & $\mathbf{A}$ & B & & \\
\hline GW-557 & $\mathrm{CR}$ & $\mathrm{R} / \mathrm{S}$ & $\mathrm{X}$ & & & & & & & & & \\
\hline GW-558 & $\mathrm{CR}$ & & $\mathrm{X}$ & & & & & & & & & \\
\hline GW-559 & CR & & $\mathrm{X}$ & & & & & & & & & \\
\hline GW-560 & CR & $\mathrm{S}$ & $\mathrm{X}$ & & & & & & & & & \\
\hline GW-562 & CR & $\mathrm{R} / \mathrm{S}$ & $\mathrm{X}$ & & & & & & & & & \\
\hline GW-564 & CR & $\mathrm{S}$ & $\mathrm{X}$ & & & & & & & & & \\
\hline GW-601 & $\mathrm{BC}$ & & & $\mathrm{X}$ & Annual & $\mathrm{X}$ & & $\mathrm{X}$ & & & & Semiannual \\
\hline GW-603 & $\mathrm{EF}$ & & $\mathrm{X}$ & & & & & & & & & \\
\hline GW-605 & $\mathrm{EF}$ & $\mathrm{R} / \mathrm{C}$ & $\mathrm{X}$ & & & & & & & & & \\
\hline GW-606 & $\mathrm{EF}$ & $\mathrm{R} / \mathrm{C}$ & $\mathrm{X}$ & & & $\mathrm{X}$ & & $X$ & & & & \\
\hline GW-608 & CR & $\mathrm{R}$ * & $\mathrm{X}$ & $\mathrm{X}$ & Even & & & & & & $\mathrm{X}$ & Annual \\
\hline GW-609 & CR & $\mathrm{R} *$ & $\mathrm{X}$ & $\mathrm{X}$ & Even & & & & & & $\mathrm{X}$ & Biennial \\
\hline GW-610 & CR & & $\mathrm{X}$ & & & & & & & & & \\
\hline GW-611 & CR & & $\mathrm{X}$ & & & & & & & & & \\
\hline GW-612 & CR & & $\mathrm{X}$ & $\mathrm{X}$ & 2013 & & & $\mathrm{X}$ & & & & Every 5 years \\
\hline GW-613 & $\mathrm{BC}$ & & $\mathrm{X}$ & & & & & & & & & \\
\hline GW-615 & $\mathrm{BC}$ & $\mathrm{R}$ * & & $\mathrm{X}$ & Annual & $\mathrm{X}$ & $\mathrm{X}$ & $\mathrm{X}$ & $\mathrm{X}$ & $X$ & & Eliminate \\
\hline GW-616 & $\mathrm{BC}$ & & & $\mathrm{X}$ & Annual & $\mathrm{X}$ & & & & & & Annual \\
\hline GW-617 & EF & & $\mathrm{X}$ & $\mathrm{X}$ & 2013 & & & & & & $\mathrm{X}$ & Eliminate \\
\hline GW-618 & $\mathrm{EF}$ & $\mathrm{C}$ & & & & & & & & & & \\
\hline GW-619 & $\mathrm{EF}$ & & $\mathrm{X}$ & $\mathrm{X}$ & Even & & & $\mathrm{X}$ & & & & Biennial \\
\hline GW-620 & $\mathrm{EF}$ & & & $\mathrm{X}$ & Even & & & $\mathrm{X}$ & & & & Annual \\
\hline GW-621 & BC & & $\mathrm{X}$ & & & & & & & & & \\
\hline GW-622 & $\mathrm{BC}$ & & $\mathrm{X}$ & & & & & & & & & \\
\hline GW-623 & BC & & & $\mathrm{X}$ & Annual & & & $\mathrm{X}$ & & & & Semiannual \\
\hline GW-624 & $\mathrm{BC}$ & & $\mathrm{X}$ & & & & & & & & & \\
\hline GW-626 & $\mathrm{BC}$ & & $\mathrm{X}$ & $\mathrm{X}$ & Even & & & $X$ & & & & Eliminate \\
\hline GW-627 & $\mathrm{BC}$ & & & $\mathrm{X}$ & Semiannual & & & $X$ & & & & Semiannual \\
\hline GW-629 & $\mathrm{BC}$ & & & $\mathrm{X}$ & Semiannual & & & $\mathrm{X}$ & & & & Semiannual \\
\hline GW-630 & $\mathrm{BC}$ & & $\mathrm{X}$ & & & & & & & & & \\
\hline GW-633 & $\mathrm{EF}$ & & & $\mathrm{X}$ & Annual & $X$ & & $\mathrm{X}$ & & $\mathrm{X}$ & & Annual \\
\hline GW-638 & $\mathrm{BC}$ & & $\mathrm{X}$ & & & & & & & & & \\
\hline GW-639 & $\mathrm{BC}$ & $\mathrm{C}$ & & & & & & & & & & \\
\hline GW-641 & $\mathrm{BC}$ & & $\mathrm{X}$ & & & & & & & & & \\
\hline GW-642 & $\mathrm{BC}$ & & $\mathrm{X}$ & & & & & & & & & \\
\hline GW-645 & $\mathrm{BC}$ & & $\mathrm{X}$ & & & & & & & & & \\
\hline GW-646 & $\mathrm{BC}$ & & $\mathrm{X}$ & & & & & & & & & \\
\hline GW-648 & $\mathrm{BC}$ & & $\mathrm{X}$ & $\mathrm{X}$ & Semiannual & & & & & & $\mathrm{X}$ & Eliminate \\
\hline GW-652 & $\mathrm{BC}$ & & $\mathrm{X}$ & & & & & & & & & \\
\hline GW-653 & $\mathrm{BC}$ & & $\mathrm{X}$ & $\mathrm{X}$ & Annual & & & $\mathrm{X}$ & & & & Semiannual \\
\hline GW-654 & $\mathrm{BC}$ & & $\mathrm{X}$ & & & & & & & & & \\
\hline GW-656 & $\mathrm{EF}$ & & & $\mathrm{X}$ & Annual & & & $X$ & & & & Biennial \\
\hline GW-658 & $\mathrm{EF}$ & $\mathrm{C}$ & & & & & & & & & & \\
\hline GW-674 & CR & & $\mathrm{X}$ & & & & & & & & & \\
\hline GW-676 & CR & & $\mathrm{X}$ & & & & & & & & & \\
\hline GW-677 & CR & & $\mathrm{X}$ & & & & & & & & & \\
\hline GW-678 & CR & & $\mathrm{X}$ & & & & & & & & & \\
\hline GW-679 & CR & & $\mathrm{X}$ & & & & & & & & & \\
\hline GW-680 & CR & & $\mathrm{X}$ & & & & & & & & & \\
\hline GW-683 & BC & C & $\mathrm{X}$ & & & & & & & & & \\
\hline GW-684 & BC & C & $\mathrm{X}$ & & & & & & & & & \\
\hline
\end{tabular}


Table B.1 (continued)

\begin{tabular}{|c|c|c|c|c|c|c|c|c|c|c|c|c|}
\hline \multirow{3}{*}{ Well } & \multirow{3}{*}{ Regime $^{1}$} & \multicolumn{3}{|c|}{ Active Status Criteria } & \multirow{3}{*}{$\begin{array}{c}\text { GWPP } \\
\text { Sampling } \\
\text { Frequency }^{3}\end{array}$} & \multicolumn{6}{|c|}{ Monitoring Criteria } & \multirow{3}{*}{$\begin{array}{c}\text { Supplemtal } \\
\text { MAROS } \\
\text { Evaluation }^{6}\end{array}$} \\
\hline & & \multirow{2}{*}{$\begin{array}{c}\text { Reg. }^{2} \\
\text { Program }\end{array}$} & \multirow{2}{*}{$\begin{array}{c}\text { Hydro- } \\
\text { logic }\end{array}$} & \multirow{2}{*}{$\begin{array}{l}\text { DOE } \\
\text { Order }\end{array}$} & & \multicolumn{5}{|c|}{ Contamination $^{4}$} & \multirow{2}{*}{$\begin{array}{c}\text { Unique } \\
\text { Char. }^{5}\end{array}$} & \\
\hline & & & & & & $\mathbf{N}$ & $\mathbf{U}$ & $\mathbf{V}$ & $\mathbf{A}$ & B & & \\
\hline GW-685 & $\mathrm{BC}$ & & $\bar{X}$ & & & & & & & & & \\
\hline GW-686 & $\mathrm{EF}$ & & $\mathrm{X}$ & $\mathrm{X}$ & Annual & & & $\mathrm{X}$ & & & & Annual \\
\hline GW-690 & $\mathrm{EF}$ & & & $\mathrm{X}$ & Annual & & & $\mathrm{X}$ & & & & Annual \\
\hline GW-691 & $\mathrm{EF}$ & & $\mathrm{X}$ & $\mathrm{X}$ & Semiannual & & & $\mathrm{X}$ & & & & Semiannual \\
\hline GW-692 & $\mathrm{EF}$ & & & $\mathrm{X}$ & Annual & & & $\mathrm{X}$ & & & & Annual \\
\hline GW-695 & $\mathrm{BC}$ & & $\mathrm{X}$ & & & & & & & & & \\
\hline GW-696 & $\mathrm{EF}$ & & $\mathrm{X}$ & & & & & & & & & \\
\hline GW-698 & $\mathrm{EF}$ & & & $\mathrm{X}$ & Semiannual & $\mathrm{X}$ & & $\mathrm{X}$ & & & & Semiannual \\
\hline GW-700 & $\mathrm{EF}$ & & & $\mathrm{X}$ & Annual & & & $\mathrm{X}$ & & & & Annual \\
\hline GW-703 & $\mathrm{BC}$ & & & $\mathrm{X}$ & Annual & $\mathrm{X}$ & & $\mathrm{X}$ & & $\mathrm{X}$ & & Annual \\
\hline GW-704 & $\mathrm{BC}$ & $\mathrm{C}$ & & & & & & & & & & \\
\hline GW-706 & $\mathrm{BC}$ & $\mathrm{C}$ & & & & & & & & & & \\
\hline GW-709 & CR & $\mathrm{S}$ & $\mathrm{X}$ & & & & & & & & & \\
\hline GW-712 & $\mathrm{BC}$ & $\mathrm{R} / \mathrm{C}$ & & & & & & & & & & \\
\hline GW-713 & $\mathrm{BC}$ & $\mathrm{R} / \mathrm{C}$ & $\mathrm{X}$ & & & & & & & & & \\
\hline GW-714 & $\mathrm{BC}$ & $\mathrm{R} / \mathrm{C}$ & & & & & & & & & & \\
\hline GW-715 & $\mathrm{BC}$ & & $\mathrm{X}$ & & & & & & & & & \\
\hline GW-722 & EF & $\mathrm{C}$ & & $\mathrm{X}$ & Annual & & & $\mathrm{X}$ & & & WB (5) & - \\
\hline GW-724 & $\mathrm{BC}$ & & & $\mathrm{X}$ & Annual & $\mathrm{X}$ & & $\mathrm{X}$ & & & & Annual \\
\hline GW-725 & $\mathrm{BC}$ & & & $\mathrm{X}$ & Annual & $\mathrm{X}$ & & $\mathrm{X}$ & & & & Annual \\
\hline GW-726 & $\mathrm{BC}$ & & & $\mathrm{X}$ & 2009/2014 & & $\mathrm{X}$ & & & & WB (8) & - \\
\hline GW-727 & $\mathrm{BC}$ & & & $\mathrm{X}$ & TBD & & & & & & WB (10) & - \\
\hline GW-729 & $\mathrm{BC}$ & & & $\mathrm{X}$ & TBD & & & & & & WB (10) & - \\
\hline GW-730 & $\mathrm{BC}$ & & & $\mathrm{X}$ & TBD & & & & & & WB (8) & - \\
\hline GW-731 & CR & $\mathrm{R}$ & $\mathrm{X}$ & & & & & & & & & \\
\hline GW-732 & CR & $\mathrm{R}$ & $\mathrm{X}$ & & & & & & & & & \\
\hline GW-733 & $\mathrm{EF}$ & $\mathrm{R} / \mathrm{C}$ & $\mathrm{X}$ & & & & & & & & & \\
\hline GW-734 & $\mathrm{EF}$ & $\mathrm{C}$ & $\mathrm{X}$ & & & & & & & & & \\
\hline GW-735 & $\mathrm{EF}$ & $\mathrm{C}$ & $\mathrm{X}$ & $\mathrm{X}$ & Odd & & & & & & $\mathrm{X}$ & Annual \\
\hline GW-738 & $\mathrm{BC}$ & & & $\mathrm{X}$ & Annual & $X$ & & $\mathrm{X}$ & & $\mathrm{X}$ & & Annual \\
\hline GW-740 & $\mathrm{BC}$ & & $\mathrm{X}$ & $\mathrm{X}$ & Annual & & & $\mathrm{X}$ & & & & Annual \\
\hline GW-743 & CR & & $\mathrm{X}$ & & & & & & & & & \\
\hline GW-744 & $\mathrm{EF}$ & $\mathrm{C}$ & & $\mathrm{X}$ & Annual & & & & & & $\mathrm{X}$ & - \\
\hline GW-746 & $\mathrm{EF}$ & & $\mathrm{X}$ & & & & & & & & & \\
\hline GW-747 & $\mathrm{EF}$ & $\mathrm{C}$ & & $\mathrm{X}$ & Annual & & & & & & $\mathrm{X}$ & - \\
\hline GW-748 & EF & & $\mathrm{X}$ & $\mathrm{X}$ & Even & & & & & & $\mathrm{X}$ & Biennial \\
\hline GW-750 & $\mathrm{EF}$ & $\mathrm{C}$ & & $\mathrm{X}$ & Odd & & & & & & $\mathrm{X}$ & Biennial \\
\hline GW-752 & EF & & $\mathrm{X}$ & & & & & & & & & \\
\hline GW-754 & $\mathrm{EF}$ & & $\mathrm{X}$ & & & & & & & & & \\
\hline GW-756 & EF & & $\mathrm{X}$ & & & & & & & & & \\
\hline GW-757 & CR & $\mathrm{S}$ & $\mathrm{X}$ & & & & & & & & & \\
\hline GW-759 & $\mathrm{EF}$ & & $\mathrm{X}$ & & & & & & & & & \\
\hline GW-761 & $\mathrm{EF}$ & & $\mathrm{X}$ & & & & & & & & & \\
\hline GW-762 & $\mathrm{EF}$ & $\mathrm{C}$ & & & & & & & & & & \\
\hline GW-763 & $\mathrm{EF}$ & $\mathrm{C}$ & $\mathrm{X}$ & $\mathrm{X}$ & Annual & & & $\mathrm{X}$ & & & & Annual \\
\hline GW-765 & EF & & $\mathrm{X}$ & $\mathrm{X}$ & Odd & & & & & & $\mathrm{X}$ & Biennial \\
\hline GW-767 & $\mathrm{EF}$ & & $\mathrm{X}$ & & & & & & & & & \\
\hline GW-769 & EF & & & $\mathrm{X}$ & Semiannual & & & $\mathrm{X}$ & & & & Semiannual \\
\hline GW-770 & EF & & $\mathrm{X}$ & $\mathrm{X}$ & Annual & & & $\mathrm{X}$ & & & & Semiannual \\
\hline GW-774 & $\mathrm{EF}$ & & $\mathrm{X}$ & & & & & & & & & \\
\hline
\end{tabular}


Table B.1 (continued)

\begin{tabular}{|c|c|c|c|c|c|c|c|c|c|c|c|c|}
\hline \multirow{3}{*}{ Well } & \multirow{3}{*}{ Regime $^{1}$} & \multicolumn{3}{|c|}{ Active Status Criteria } & \multirow{3}{*}{$\begin{array}{c}\text { GWPP } \\
\text { Sampling } \\
\text { Frequency }^{3}\end{array}$} & \multicolumn{6}{|c|}{ Monitoring Criteria } & \multirow{3}{*}{$\begin{array}{c}\text { Supplemtal } \\
\text { MAROS } \\
\text { Evaluation }^{6}\end{array}$} \\
\hline & & \multirow{2}{*}{$\begin{array}{c}\text { Reg. }^{2} \\
\text { Program }\end{array}$} & \multirow{2}{*}{$\begin{array}{c}\text { Hydro- } \\
\text { logic }\end{array}$} & \multirow{2}{*}{$\begin{array}{l}\text { DOE } \\
\text { Order }\end{array}$} & & \multicolumn{5}{|c|}{ Contamination ${ }^{4}$} & \multirow{2}{*}{$\begin{array}{l}\text { Unique } \\
\text { Char. }^{5}\end{array}$} & \\
\hline & & & & & & $\mathbf{N}$ & $\mathbf{U}$ & $\overline{\mathbf{V}}$ & $\overline{\mathbf{A}}$ & $\overline{\mathbf{B}}$ & & \\
\hline GW-775 & $\mathrm{EF}$ & & & $\mathrm{X}$ & Odd & & & $\mathrm{X}$ & & & & Biennial \\
\hline GW-776 & $\mathrm{EF}$ & & $\mathrm{X}$ & $\mathrm{X}$ & Odd & & & & & & $\mathrm{X}$ & Biennial \\
\hline GW-778 & $\mathrm{EF}$ & & $\mathrm{X}$ & & & & & & & & & \\
\hline GW-779 & $\mathrm{EF}$ & & & $\mathrm{X}$ & Odd & & & & & & $\mathrm{X}$ & Biennial \\
\hline GW-781 & $\mathrm{EF}$ & & & $\mathrm{X}$ & Annual & & & & & & $\mathrm{X}$ & Annual \\
\hline GW-782 & $\mathrm{EF}$ & & & $\mathrm{X}$ & Annual & & & $\mathrm{X}$ & $\mathrm{X}$ & & & Annual \\
\hline GW-783 & $\mathrm{EF}$ & & $\mathrm{X}$ & $\mathrm{X}$ & Annual & & & $\mathrm{X}$ & & & & Annual \\
\hline GW-790 & $\mathrm{BC}$ & & & $\mathrm{X}$ & TBD & & & & & & WB (10) & - \\
\hline GW-791 & $\mathrm{EF}$ & & & $\mathrm{X}$ & Annual & & & $\mathrm{X}$ & & & & Annual \\
\hline GW-792 & $\mathrm{EF}$ & & $\mathrm{X}$ & $\mathrm{X}$ & Even & & & $\mathrm{X}$ & & & & Biennial \\
\hline GW-795 & $\mathrm{BC}$ & & $\mathrm{X}$ & & & & & & & & & \\
\hline GW-796 & CR & $\mathrm{R} / \mathrm{S}$ & $\mathrm{X}$ & & & & & & & & & \\
\hline GW-797 & CR & $\mathrm{S} / \mathrm{C}$ & $\mathrm{X}$ & & & & & & & & & \\
\hline GW-798 & CR & $\mathrm{S} / \mathrm{C}$ & $\mathrm{X}$ & & & & & & & & & \\
\hline GW-799 & CR & $\mathrm{R} / \mathrm{S}$ & $\mathrm{X}$ & & & & & & & & & \\
\hline GW-800 & $\mathrm{BC}$ & & $\mathrm{X}$ & & & & & & & & & \\
\hline GW-801 & CR & $\mathrm{R} / \mathrm{S}$ & $\mathrm{X}$ & & & & & & & & & \\
\hline GW-802 & $\mathrm{EF}$ & $\mathrm{C}$ & & & & & & & & & & \\
\hline GW-816 & $\mathrm{EF}$ & & $\mathrm{X}$ & $\mathrm{X}$ & Annual & & & & & & $\mathrm{X}$ & Annual \\
\hline GW-820 & $\mathrm{EF}$ & & & $\mathrm{X}$ & Annual & & & $\mathrm{X}$ & & & & Annual \\
\hline GW-827 & CR & $\mathrm{S}$ & $\mathrm{X}$ & & & & & & & & & \\
\hline GW-829 & $\mathrm{BC}$ & & $\mathrm{X}$ & $\mathrm{X}$ & Even & $\mathrm{X}$ & & & & & & Annual \\
\hline GW-831 & CR & $\mathrm{R}$ & $\mathrm{X}$ & & & & & & & & & \\
\hline GW-832 & $\mathrm{EF}$ & $\mathrm{C}$ & * & & & & & & & & & \\
\hline GW-835 & $\mathrm{BC}$ & $\mathrm{C}$ & $\mathrm{X}$ & & & & & & & & & \\
\hline GW-841 & CR & $\mathrm{C}$ & & & & & & & & & & \\
\hline GW-842 & CR & $\mathrm{C}$ & & & & & & & & & & \\
\hline GW-845 & $\mathrm{EF}$ & C & & & & & & & & & & \\
\hline GW-916 & $\mathrm{BC}$ & C & $\mathrm{X}$ & & & & & & & & & \\
\hline GW-917 & $\mathrm{BC}$ & C & $\mathrm{X}$ & & & & & & & & & \\
\hline GW-918 & $\mathrm{BC}$ & $\mathrm{C}$ & $\mathrm{X}$ & & & & & & & & & \\
\hline GW-920 & $\mathrm{BC}$ & C & & & & & & & & & & \\
\hline GW-921 & $\mathrm{BC}$ & $\mathrm{C}$ & $\mathrm{X}$ & & & & & & & & & \\
\hline GW-922 & $\mathrm{BC}$ & C & $\mathrm{X}$ & & & & & & & & & \\
\hline GW-923 & $\mathrm{BC}$ & $\mathrm{C}$ & $\mathrm{X}$ & & & & & & & & & \\
\hline GW-924 & $\mathrm{BC}$ & C & $\mathrm{X}$ & & & & & & & & & \\
\hline GW-925 & $\mathrm{BC}$ & $\mathrm{C}$ & & & & & & & & & & \\
\hline GW-926 & $\mathrm{BC}$ & C & & & & & & & & & & \\
\hline GW-927 & $\mathrm{BC}$ & $\mathrm{C}$ & & & & & & & & & & \\
\hline GW-934 & $\mathrm{EF}$ & & & $\mathrm{X}$ & TBD & & & $\mathrm{X}$ & & & WB(10) & - \\
\hline GW-954 & EF & & & $\mathrm{X}$ & TBD & & & & & & $\mathrm{BCAD(3)}$ & Annual \\
\hline GW-956 & EF & & & $\mathrm{X}$ & TBD & & & $\mathrm{X}$ & & & $\mathrm{BCAD}(4)$ & Annual \\
\hline GW-959 & EF & & $\mathrm{X}$ & $\mathrm{X}$ & Odd & & & $\mathrm{X}$ & & & & Annual \\
\hline GW-960 & $\mathrm{EF}$ & & $\mathrm{X}$ & $\mathrm{X}$ & Odd & & & & & & $\mathrm{X}$ & Annual \\
\hline
\end{tabular}

Notes:

1 Regime

\footnotetext{
$\mathrm{BC}=$ Bear Creek Hydrogeologic Regime

$\mathrm{CR}=$ Chestnut Ridge Hydrogeologic Regime

EF = Upper East Fork Poplar Creek Hydrogeologic Regime
} 


\section{Table B.1 (continued)}

Notes (continued):

2 Regulatory Program

$$
\begin{aligned}
\mathrm{C} & =\text { CERCLA } \\
\mathrm{C}(\mathrm{wl}) & =\text { CERCLA, water level monitoring only (East End VOC Plume Removal) } \\
\mathrm{R} & =\text { RCRA } \\
\mathrm{R} * & =\text { RCRA point-of-compliance well not currently sampled for RCRA monitoring } \\
\mathrm{S} & =\text { Solid Waste Disposal Facility }
\end{aligned}
$$

3 Sampling Frequency for the Y-12 GWPP, as determined from the

supplemental MAROS recommendation and subsequent professional judgement.

$$
\begin{aligned}
\text { even } & =\text { Biennial sampling, during even years } \\
\text { odd } & =\text { Biennial sampling, during odd years } \\
\text { TBD } & =\text { To be determined; retained for possible water quality monitoring } \\
& =\text { Sampling frequency differs from the MAROS recommendation }
\end{aligned}
$$

4 Contamination: Indicates principal groundwater contaminant concentrations that exceed screening levels, listed in the following sequence.

$$
\begin{aligned}
& \mathrm{N}=\text { Nitrate }>10 \mathrm{mg} / \mathrm{L} \\
& \mathrm{V}=\text { VOCs }>5 \mu \mathrm{g} / \mathrm{L}, \text { summed concentrations } \\
& \mathrm{U}=\text { Uranium }>0.03 \mathrm{mg} / \mathrm{L} \\
& \mathrm{A}=\text { Gross Alpha Activity }>15 \mathrm{pCi} / \mathrm{L} \\
& \mathrm{B}=\text { Gross Beta Activity }>50 \mathrm{pCi} / \mathrm{L}
\end{aligned}
$$

5 Unique Characteristics

$$
\begin{aligned}
\mathrm{BCAD} & =\text { Well equipped with Barcad }{ }^{\mathrm{TM}} \text { system (number of discrete sampling zones) } \\
\mathrm{WB} & =\text { Well equipped with Westbay }{ }^{\mathrm{TM}} \text { multiport sampling equipment (number of discrete sampling zones) } \\
\mathrm{X} & =\text { Selected because of location of monitoring well }
\end{aligned}
$$

6 Supplemental MAROS Evaluation: recommended sampling frequency for wells selected for monitoring by the Y-12 GWPP.

$\begin{aligned}- & =\text { Omitted from the MARO } \\ \text { Eliminate } & =\text { Discontinue sampling }\end{aligned}$ 
Table B.2. Groundwater monitoring wells that are granted inactive status under the Y-12 Groundwater Protection Program

\begin{tabular}{|c|c|c|c|c|c|c|c|}
\hline Well & Regime $^{1}$ & Well & Regime $^{1}$ & Well & Regime $^{1}$ & Well & Regime $^{1}$ \\
\hline $53-1 \mathrm{~A}$ & $\mathrm{EF}$ & GW-147 & CR & GW-333 & $E F$ & GW-699 & $E F$ \\
\hline $54-2 \mathrm{~A}$ & $\mathrm{EF}$ & GW-150 & $\mathrm{EF}$ & GW-336 & $\mathrm{EF}$ & GW-701 & EF \\
\hline $55-1 B$ & $\mathrm{EF}$ & GW-158 & CR & GW-338 & EF & GW-702 & EF \\
\hline $55-1 C$ & $\mathrm{EF}$ & GW-162 & $\mathrm{BC}$ & GW-342 & $\mathrm{BC}$ & GW-705 & $\mathrm{BC}$ \\
\hline 56-7A & $\mathrm{EF}$ & GW-163 & BC & GW-343 & $\mathrm{BC}$ & GW-710 & $\mathrm{BC}$ \\
\hline $58-2 \mathrm{~A}$ & $\mathrm{EF}$ & GW-164 & BC & GW-344 & $\mathrm{BC}$ & GW-711 & $\mathrm{BC}$ \\
\hline $59-1 \mathrm{~A}$ & $\mathrm{EF}$ & GW-165 & CR & GW-346 & $\mathrm{BC}$ & GW-723 & BC \\
\hline $59-1 B$ & $\mathrm{EF}$ & GW-166 & CR & GW-348 & $\mathrm{BC}$ & GW-736 & $\mathrm{BC}$ \\
\hline $59-1 C$ & $\mathrm{EF}$ & GW-181 & CR & GW-350 & $\mathrm{EF}$ & GW-737 & $\mathrm{BC}$ \\
\hline $60-1 \mathrm{~B}$ & $\mathrm{EF}$ & GW-183 & EF & GW-366 & BC & GW-739 & $\mathrm{BC}$ \\
\hline CH-143 & CR & GW-185 & CR & GW-368 & $\mathrm{BC}$ & GW-742 & CR \\
\hline CH-157 & CR & GW-187 & CR & GW-369 & $\mathrm{BC}$ & GW-745 & $\mathrm{EF}$ \\
\hline CH-185 & CR & GW-189 & CR & GW-371 & $\mathrm{BC}$ & GW-751 & EF \\
\hline CH-189 & CR & GW-191 & $\mathrm{EF}$ & GW-373 & $\mathrm{BC}$ & GW-753 & $\mathrm{EF}$ \\
\hline GW-011 & BC & GW-194 & EF & GW-374 & $\mathrm{BC}$ & GW-755 & EF \\
\hline GW-013 & $\mathrm{BC}$ & GW-196 & $\mathrm{EF}$ & GW-375 & $\mathrm{BC}$ & GW-758 & EF \\
\hline GW-015 & $\mathrm{BC}$ & GW-197 & EF & GW-376 & $\mathrm{BC}$ & GW-760 & EF \\
\hline GW-017 & BC & GW-198 & EF & GW-385 & $\mathrm{EF}$ & GW-764 & EF \\
\hline GW-018 & BC & GW-206 & EF & GW-513 & CR & GW-766 & EF \\
\hline GW-040 & $\mathrm{BC}$ & GW-207 & $\mathrm{EF}$ & GW-520 & $\mathrm{BC}$ & GW-768 & $\mathrm{EF}$ \\
\hline GW-042 & $\mathrm{BC}$ & GW-208 & EF & GW-532 & $\mathrm{BC}$ & GW-773 & EF \\
\hline GW-045 & $\mathrm{BC}$ & GW-218 & $\mathrm{EF}$ & GW-533 & $\mathrm{BC}$ & GW-777 & $\mathrm{EF}$ \\
\hline GW-054 & $\mathrm{BC}$ & GW-224 & CR & GW-534 & $\mathrm{BC}$ & GW-794 & BC \\
\hline GW-055 & $\mathrm{BC}$ & GW-228 & $\mathrm{BC}$ & GW-535 & $\mathrm{BC}$ & GW-803 & $\mathrm{EF}$ \\
\hline GW-056 & $\mathrm{BC}$ & GW-232 & EF & GW-538 & $\mathrm{BC}$ & GW-804 & EF \\
\hline GW-061 & BC & GW-237 & BC & GW-563 & CR & GW-811 & BC \\
\hline GW-062 & $\mathrm{BC}$ & GW-239 & EF & GW-567 & CR & GW-812 & BC \\
\hline GW-064 & $\mathrm{BC}$ & GW-248 & $\mathrm{BC}$ & GW-569 & CR & GW-813 & $\mathrm{BC}$ \\
\hline GW-066 & $\mathrm{BC}$ & GW-250 & $\mathrm{BC}$ & GW-576 & CR & GW-814 & $\mathrm{BC}$ \\
\hline GW-070 & $\mathrm{BC}$ & GW-252 & $\mathrm{EF}$ & GW-602 & $\mathrm{BC}$ & GW-815 & $\mathrm{BC}$ \\
\hline GW-072 & $\mathrm{BC}$ & GW-258 & $\mathrm{BC}$ & GW-604 & $\mathrm{EF}$ & GW-819 & $\mathrm{EF}$ \\
\hline GW-073 & $\mathrm{BC}$ & GW-262 & $\mathrm{EF}$ & GW-614 & $\mathrm{BC}$ & GW-828 & $\mathrm{BC}$ \\
\hline GW-074 & $\mathrm{BC}$ & GW-264 & EF & GW-625 & $\mathrm{BC}$ & GW-834 & $\mathrm{BC}$ \\
\hline GW-081 & BC & GW-268 & EF & GW-628 & $\mathrm{BC}$ & GW-836 & BC \\
\hline GW-083 & $\mathrm{BC}$ & GW-271 & EF & GW-631 & $\mathrm{EF}$ & GW-843 & CR \\
\hline GW-094 & $\mathrm{BC}$ & GW-273 & $\mathrm{EF}$ & GW-634 & $\mathrm{EF}$ & GW-844 & CR \\
\hline GW-095 & $\mathrm{BC}$ & GW-277 & $\mathrm{BC}$ & GW-636 & $\mathrm{BC}$ & & \\
\hline GW-096 & BC & GW-282 & EF & GW-637 & $\mathrm{BC}$ & & \\
\hline GW-097A & $\mathrm{BC}$ & GW-283 & $\mathrm{EF}$ & GW-640 & $\mathrm{BC}$ & & \\
\hline GW-117 & BC & GW-284 & EF & GW-643 & $\mathrm{BC}$ & & \\
\hline GW-118 & $\mathrm{BC}$ & GW-285 & EF & GW-647 & $\mathrm{BC}$ & & \\
\hline GW-119 & BC & GW-286 & BC & GW-649 & $\mathrm{BC}$ & & \\
\hline GW-120 & $\mathrm{BC}$ & GW-288 & $\mathrm{BC}$ & GW-651 & $\mathrm{BC}$ & & \\
\hline GW-121 & $\mathrm{BC}$ & GW-290 & $\mathrm{BC}$ & GW-655 & $\mathrm{BC}$ & & \\
\hline GW-123 & $\mathrm{BC}$ & GW-308 & BC & GW-657 & $\mathrm{EF}$ & & \\
\hline GW-124 & $\mathrm{BC}$ & GW-311 & $\mathrm{BC}$ & GW-659 & $\mathrm{EF}$ & & \\
\hline GW-125 & $\mathrm{BC}$ & GW-313 & $\mathrm{BC}$ & GW-673 & CR & & \\
\hline GW-126 & BC & GW-314 & $\mathrm{BC}$ & GW-681 & CR & & \\
\hline GW-131 & $\mathrm{EF}$ & GW-317 & BC & GW-682 & CR & & \\
\hline GW-132 & $\mathrm{EF}$ & GW-318 & CR & GW-688 & EF & & \\
\hline GW-133 & $\mathrm{BC}$ & GW-319 & CR & GW-693 & $\mathrm{EF}$ & & \\
\hline GW-135 & $\mathrm{BC}$ & GW-324 & $\mathrm{BC}$ & GW-694 & $\mathrm{BC}$ & & \\
\hline GW-146 & CR & GW-331 & $\mathrm{EF}$ & GW-697 & $\mathrm{EF}$ & & \\
\hline
\end{tabular}


Table B.2. (continued)

Notes:

1 Regime

$\mathrm{BC}=$ Bear Creek Hydrogeologic Regime

$\mathrm{CR}=$ Chestnut Ridge Hydrogeologic Regime

$\mathrm{EF}=$ Upper East Fork Poplar Creek Hydrogeologic Regime 
APPENDIX C

ADDENDA

(if issued) 


\section{DISTRIBUTION}

\section{U.S. DEPARTMENT OF ENERGY}

J. P. Donnelly *

ENVIRONMENTAL COMPLIANCE DEPARTMENT

S. M. Field

C. C. Hill

S. L. Jollay *

S. B. Jones *

L. W. McMahon

S. E. McNamara*

B. F. Scott

L. O. Vaughan

INFORMATION TECHNOLOGY

S. W. King

Y-12 Central Files *

9114DMC-01971865.6550-RC

Y-12 Records Services (Electronic copy- OSTI)

YDCC - RC *
TENNESSEE DEPARTMENT OF

ENVIRONMENT AND CONSERVATION

DOE OVERSIGHT

J. E. Sebastian *

ELVADO ENVIRONMENTAL LLC

T. R. Harrison *

J.R. Walker *

BECHTEL JACOBS COMPANY LLC

E. L. Berglund

H. K. Haase

R. H. Ketelle

L. M. Sims *

R. S. Williams

File-EMEF-DMC *

UT-BATTELLE, LLC

J.F. Hughes

D. B. Watson

Note: ${ }^{*}=$ receives hard copy 